$$
\begin{gathered}
\text { UNIVERSITY OF CALIFORNIA } \\
\text { COLLEGE OF AGRICULTURE } \\
\text { AGRICULTURAL EXPERIMENT STATION } \\
\text { BERKELEY, CALIFORNIA }
\end{gathered}
$$

\title{
LABORATORY TESTS OF ORCHARD HEATERS
}

\author{
A. H. HOFFMAN
}

\section{BULLETIN 442}

NOVEMBER, 1927 
Digitized by the Internet Archive in 2012 with funding from University of California, Davis Libraries 


\title{
LABORATORY TESTS OF ORCHARD HEATERS*
}

\author{
A. H. HOFFMAN'
}

Field studies of the economic phases of orchard heating have been made by Young, ${ }^{(9,10,11,12)}$ Young and Cate, ${ }^{(13)}$ Schoonover, Hodgson and Young, ${ }^{(6)}$ West and Edlefsen, ${ }^{(8)}$ Webber et al., ${ }^{(7)}$ Garcia and Fite, ${ }^{(1)}$ and others. Tests to determine the effectiveness of different orchard heaters to stay the fall of temperature have been made in large number and variety by Young, ${ }^{(9,10,11,12)}$ West and Edlefsen, ${ }^{(8)}$ $\mathrm{O}$ 'Gara, ${ }^{(4)}$ and others. Aside from some measurements of radiation made by Kimball and Young, ${ }^{(3)}$ exact measurements of the performance of the individual heaters have in general been lacking and are needed for the guidance of both the user and the manufacturer. At the urgent request of the Citrus Growers' Department of the Southern California Farm Bureaus and others the work here reported was undertaken. In general it has been found that the methods which mechanical engineers commonly use in testing the performance characteristics of steam-boiler furnaces and the like are inapplicable to orchard heaters for the reason that the latter, burning in the open, present an entirely different problem. Hence it has been found necessary to devise new methods and apparatus.

\section{THE IDEAL ORCHARD HEATER}

Those who have made the most thorough study of the subject are generally agreed that the following characteristics in an orchard heater are desirable for reasons obvious or specified.

1. It should be able to burn fuel (and hence to produce heat) at rates that will enable the fruit grower to control the temperature of his orchard within the necessary limits. The only practical method yet found for preventing frost damage in orchards is by adding heat to the air.

2. It should burn the fuel completely so that all the heat contained may be liberated.

* The purpose of this bulletin is to make the results of these studies immediately available to the user and to the manufacturer of orchard heaters. The test methods will be explained in a later publication.

† Associate Agricultural Engineer in the Experiment Station. 
3. Its radiation above the horizontal plane should not be excessive.

4. The gases rising from the stacks should be discharged at a level close to the ground and should not have too great an upward velocity or they may be shot so high that they may not effectively warm the orchard.

5. The higher the temperature of the heater surfaces and of the gases rising from the stacks the greater will be the rate of radiation and the higher the upward velocity. It follows therefore that very high temperatures are undesirable and that as much cold air as possible should be mixed with the products of combustion before they are discharged from a heater.

6. An orchard heater should not smoke, since smoke is a general nuisance to all persons in the region. It damages ripe fruit by blacking it and rendering washing necessary, and wastes a small portion of the heat content of the fuel.

7. All the foregoing desirable characteristics should be embodied in a heater (a) that can be produced at a reasonable cost, $(b)$ that can be operated with a minimum of skill, labor and care, $(c)$ that will have a low up-keep expense and a satisfactory length of life, and $(d)$ that will burn available fuel.

\section{THE PROBLEMS TO BE SOLVED}

The following items are the principal objectives sought in this study :

1. What are the characteristic burning or fuel consumption rates of the different heaters?

2. How efficiently do they convert fuel into heat?

3. What per cent of the heat is lost by radiation?

4. How fast do the hot gases rise from the stacks of the heaters?

5. What temperatures are attained by the gases and by the heater surfaces?

6. How much smoke is produced by each heater and how may a visible record of the smokiness be obtained?

7. What characteristics are necessary in a satisfactory fuel for orchard heating? 


\section{THE HEATERS STUDIED}

A total of nineteen heaters, figure 1, and table 1, were included. Extra stacks and "spiders" for placing over lard-pail type to reduce the burning rate (see Nos. $6 \mathrm{~s}$ and $8 \mathrm{~s}$ as typical spiders) brought the actual number of heaters tested up to twenty-six. Six of these are of the briquet or solid fuel burning type, two are non-distilling, and

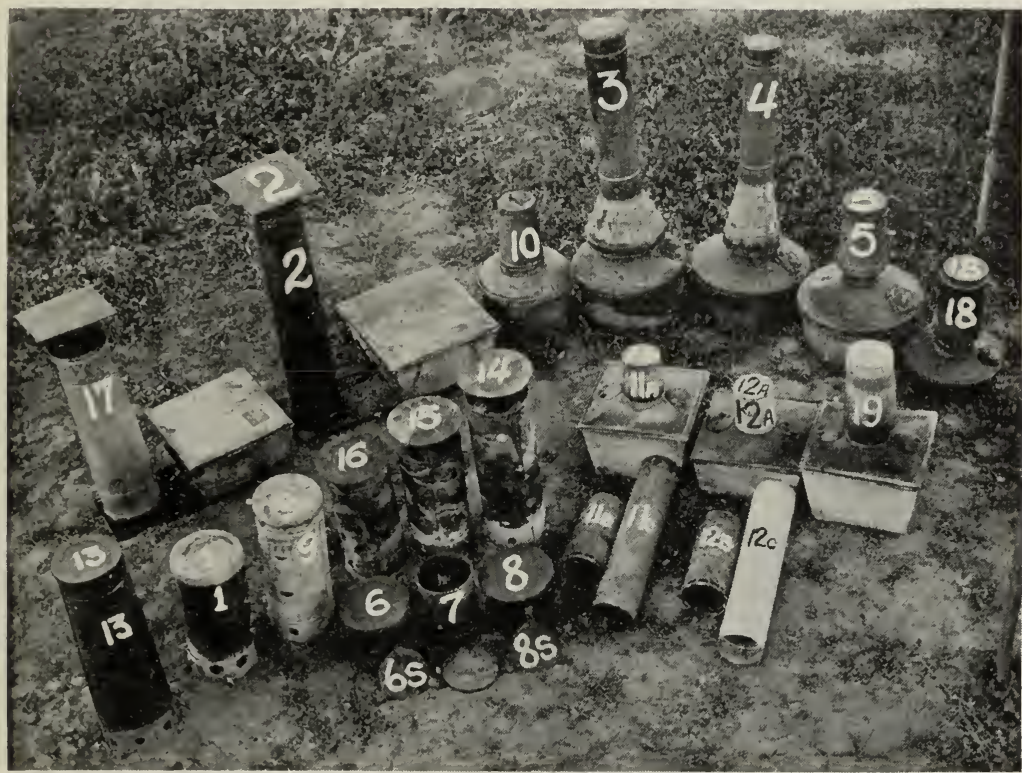

Fig. 1.-Names of the heaters tested: 1. Pomona. 2. Kittle. 3. Scheu Jumbo Cone Louvre. 4. Scheu Baby Cone Louvre. 5. Scheu Double Stack. 6. Bolton. 6s. Bolton (with spider). 7. Troutman. 8. Canco. 8s. Canco (with spider). 9. Diamond. 10A. Dunn (10 in the illustration). 10C. Dunn (with 30-inch stack; not shown). 11A. Citrus, 9-gal. low stack. 11B. Citrus, 9-gal. medium stack. 11C. Citrus, 9-gal. high stack. 12A. Citrus, 6-gal. low stack. 12B. Citrus, 6-gal. medium stack. 12C. Citrus, 6-gal. high stack. 13. Karr. 14. Jessen (large). 15. Jessen (medium). 16. Jessen (small). 17. Low Delivery. 18. Baby Double Stack. 19. Citrus Gas Flame.

eighteen distilling oil burners. Four additional heaters were received too late for test. Three of these are Citrus heaters and similar to Nos. 11B, 11C, and 19. They differ from those illustrated in that each has a baffle plate inside the reservoir and a filler tube and filler cap in the cover, and the one similar to $11 \mathrm{~B}$ also has the stack height reduced from 31 inches to 18 inches. The fourth is the new ScheuNational Jumbo Cone Louvre heater and differs from heater No. 3 of the tests in the following particulars: weight 18.3 pounds; over-all height 44 inches ; stack, height $221 / 2$ inches, top diameter 7 inches, bot- 


\begin{tabular}{|c|c|c|c|c|c|c|c|c|c|c|c|}
\hline \multirow{5}{*}{ 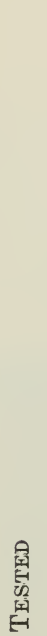 } & & \multicolumn{2}{|r|}{ 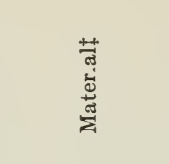 } & 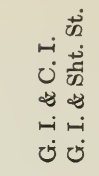 & 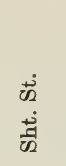 & 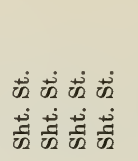 & 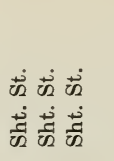 & 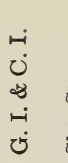 & $\begin{array}{l}\dot{0} \\
\dot{\vec{n}} \\
\dot{\tilde{n}}\end{array}$ & 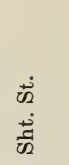 & ச் \\
\hline & & 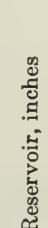 & 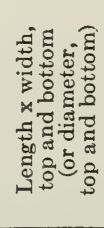 & 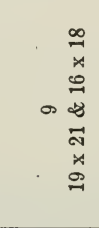 & 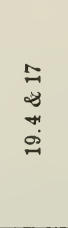 & 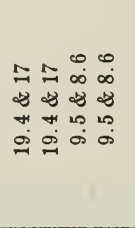 & 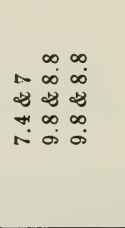 & $\infty$ & 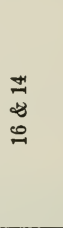 & 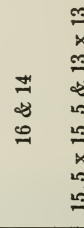 & 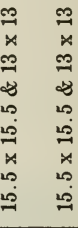 \\
\hline & & & 亚 & $\stackrel{\infty}{ \pm} \infty$ & 음 & 요요 $\ddot{\infty} \ddot{\infty}$ & $\begin{array}{lll}\infty & \infty & \infty \\
\infty & \infty & \infty \\
\infty & \infty & \infty\end{array}$ & 9 & $\stackrel{\sim}{\varrho}$ & $\stackrel{\oplus}{\varrho}$ & @ \\
\hline & & 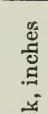 & 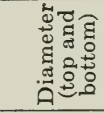 & $\begin{array}{l}\infty \\
\infty \\
\infty \\
\infty\end{array}$ & $\begin{array}{l}\infty \\
\infty \\
0\end{array}$ & 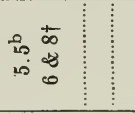 & & & $\begin{array}{l}\infty \\
\vdots \\
\infty\end{array}$ & $\begin{array}{l}0 \\
\ddot{z} \\
10\end{array}$ & ف \\
\hline & & कू & 茁 & 와 & : & 芯 & & & $\cong$ & $F$ & 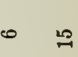 \\
\hline 舅 & & 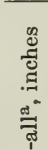 & 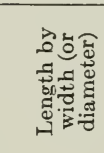 & 워 & 요 & ㅇำ 용 & 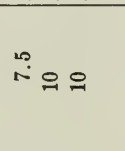 & $\stackrel{20}{\infty}$ & $=$ & 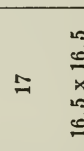 & $\begin{array}{ll}0 & 0 \\
0 & 0 \\
0 & 0 \\
* & x \\
0 & 2 \\
0 & 0 \\
0 & 0\end{array}$ \\
\hline 변 & $\underset{0}{\dot{80}}$ & ठั & 荀 & $9 \ddot{9}$ & ๓ึ & 연송ㅇㅇㅇ & $=00$ & ה & $\stackrel{\text { జ }}{ }$ & is & م) \\
\hline & $\begin{array}{l}\frac{0}{\sigma} \\
0 \\
0 \\
\tilde{D}\end{array}$ & & 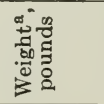 & $\begin{array}{ll}0 & 0 \\
0 & 0 \\
0\end{array}$ & జึ. & $\ddot{\oplus}=\vec{\sim} \dot{\sim}$ & 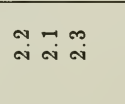 & $\stackrel{9}{0}$ & $\stackrel{ }{\dddot{\sim}}$ & $\stackrel{\infty}{2}$ & $=$ \\
\hline 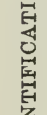 & & & 䓛 & 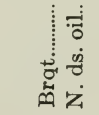 & $\begin{array}{l}\overrightarrow{0} \\
\dot{0}\end{array}$ & 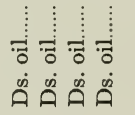 & 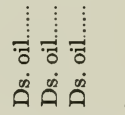 & 葱 & $\begin{array}{l}\overrightarrow{0} \\
\dot{\phi} \\
\stackrel{0}{0}\end{array}$ & $\begin{array}{cc}\overline{0} & \overline{0} \\
\dot{0} & \stackrel{0}{0}\end{array}$ & 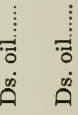 \\
\hline 舅 & & & 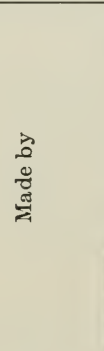 & 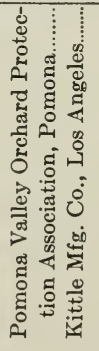 & 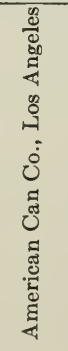 & 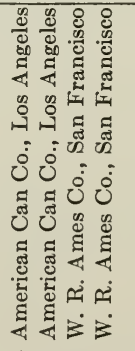 & 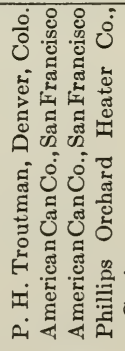 & 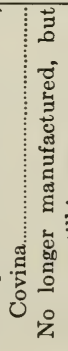 & 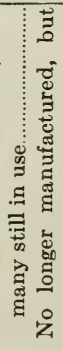 & 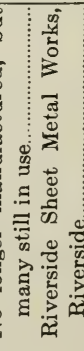 & 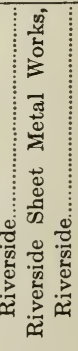 \\
\hline & & & 鹃 & 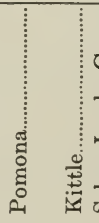 & 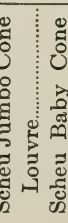 & 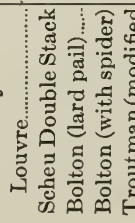 & 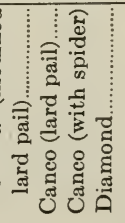 & हี & 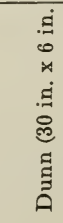 & 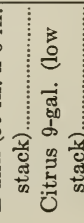 & 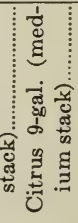 \\
\hline & & & $\dot{z}$ & $-N$ & + & 0 & $\infty \quad \infty$ & $\overleftrightarrow{\circlearrowleft}$ & ర్త & 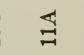 & $\Xi$ \\
\hline
\end{tabular}




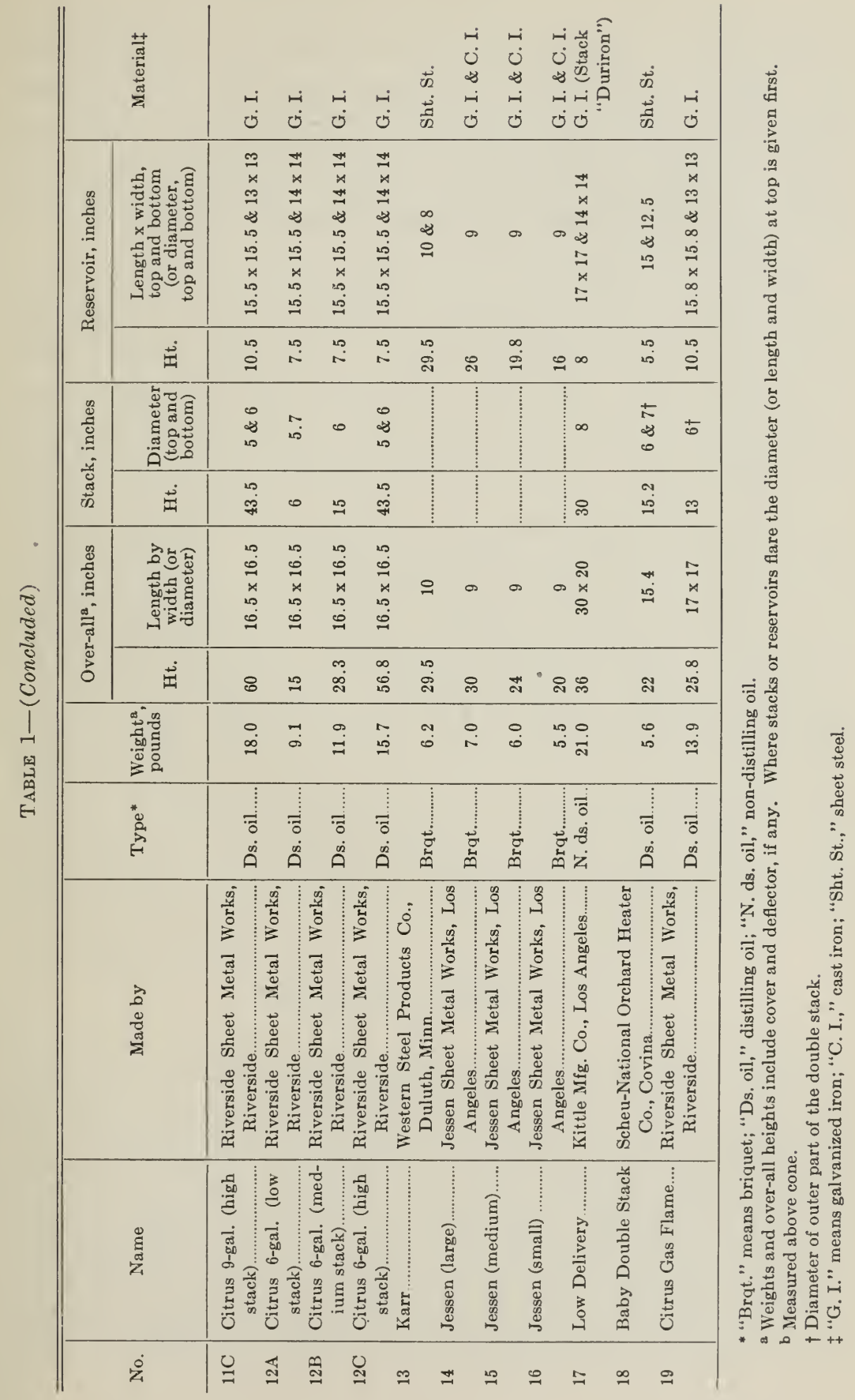


tom diameter 9 inches. The cone is larger at the top than that of No. 3 . A self-contained lighting cup is placed at the top of the down-draft tube. With the exception of the Dunn heater (no longer manufactured but many still in use), all the heaters studied were supplied by courtesy of the manufacturers. In each case the maker was asked to supply any directions for use which he had found necessary to give the buyers of his product. In the tests such instructions were followed as closely as possible.

The heaters studied are of three types or classes, (1) those that burn solid fuel, especially briquets, (2) those that burn oil in a burner separate from the fuel reservoir, and (3) those that burn oil within the reservoir itself. The names in common use for these three types, briquet, non-distilling oil, and distilling oil, are used in reporting this work, although the last two terms do not seem entirely fitting since condensation is not a feature in the operation of either type. In the so-called non-distilling heater the oil is metered through a suitable device in flowing from the reservoir to the burner. The fuel left in the reservoir after a night's burning of the heater is practically the same in quality as before lighting. In the so-called distilling type heater the fire inside the reservoir causes the more volatile portions of the oil to be vaporized and burned first. Hence, after some hours of burning, the oil remaining in the reservoir of such a heater may be considerably denser (lower Baumé number) than the original fresh oil.

Briquet heaters are not so easy to extinguish as the oil burners. They are usually left until the complete charge of fuel has burned out. Though some fuel might be saved by emptying the contents of the heaters upon the ground, generally the labor cost would be too great.

\section{THE LABORATORIES USED}

In order that the conditions under which the heaters were placed during test might be comparable with those in practice, the laboratory chosen for the bulk of the tests was a tilled field about 50 yards wide flanked on the east by a deciduous orchard and on the west by a vineyard. The only building near was a small shed built to shelter the necessary instruments. Here the tests were run at night and only when the wind speed, measured at a height of 18 feet 10 inches above the ground was less than about 5.5 miles per hour. The speed at the level of the heaters was much less. Higher wind speeds caused too great variations in the burning rates and made it impossible to obtain 
satisfactory measurements of the quantities under study. The air temperatures during the testing were not so low as is desirable but were the best available at Davis. However, it is believed that a re-running of the tests at temperatures between $18^{\circ} \mathrm{F}$ and $28^{\circ} \mathrm{F}$ would not change the relative positions of the heaters as to the measurements. Since colder air is denser and therefore contains more oxygen per cubic foot it would be expected that for a given adjustment and kind of fuel a heater would burn faster at the colder air temperature. A test indicated that this was true. An open lard-pail heater was burned four times at night and thrice in the daytime using 17 pounds of No. 2 oil (see table 7 ) for each test. The wind speeds were nearly the same for all tests. The average day burning time was 3 hours 0 minutes and air temperature $48.7^{\circ} \mathrm{F}$; the average night time 2 hours 29 minutes and air temperature $36.3^{\circ} \mathrm{F}$. See curves " 8 (day)" and " 8 " in figure 2.

In general at least two tests in the field laboratory were made on each heater, one at "high adjustment" and one at "low adjustment, meaning, respectively, about as high as a grower would ordinarily burn his heaters if he feared he might not be able to hold a safe air temperature, and about as low as the heater could be made to burn properly. In some cases it was found later that adjustments had been somewhat too high or too low. It was not always possible to re-run the test.

To make sure that the comparative records of smoke and of upward velocities of the gases were correct it was decided to make a "normal adjustment" run indoors so that wind effects might be entirely eliminated. The indoor tests were made in daytime in a large room which was ventilated after each test, the heaters being lighted and warmed up outside and brought in on a small flat-car.

\section{FUEL CONSUMPTION RATES}

From the utility standpoint the burning or fuel consumption rates are of the utmost importance since to produce heat in large quantities is the prime object. The heat produced equals the number of pounds of fuel burned times the heat content per pound, assuming complete combustion. The heat content of a fuel is generally expressed in British thermal units (abbreviated B.t.u.) per pound. Its value is about 20,000 for oil, 16,000 for coke, and 13,000 for coal. A B.t.u. is 


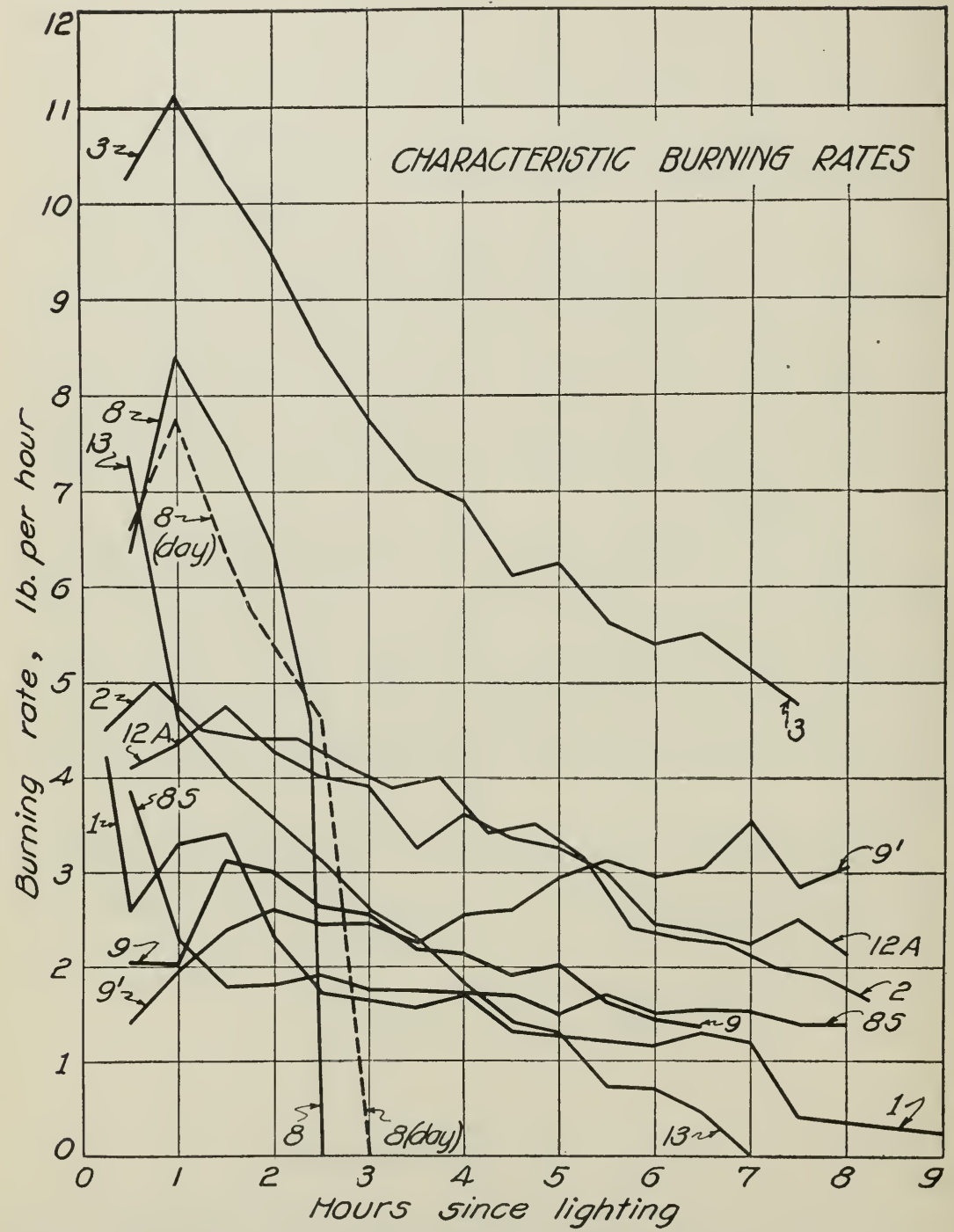

Fig. 2.-Characteristic burning rates. Each curve, except "8" and "8 (day)," is the record of a single test on the heater of the corresponding number. The fuel reservoirs were full at lighting. The only draft adjustments, if any, were made immediately after lighting. All briquet heaters were top lighted. The deviations from smooth curves are due principally to wind variations. Briquet type heaters vary more than the oil burners (curves 1, 9, 9', and 13). Curve $9^{\prime}$ shows a typical case of imperfect lighting (heater No. 9). The dotted line curve " 8 (day)" is the average of three tests run in daytime and shows how higher air temperature slows the burning rate. Curve " 8 " is the average of 4 tests all run at night. See figure 1 and table 1 for identification of heaters. 
the heat required to warm one pound of pure water one degree Fahrenheit. It is comparatively easy to measure burning rates. For the field tests the scales used were sensitive to one-fourth ounce and were set into the ground so that the bottom of each heater was on a level with the ground surface. Readings of weights were taken at 30-minute intervals in the field laboratory and at 10-minute intervals indoors. It was found that the burning rates of distilling type oil burning, and of briquet burning heaters were greatly affected by slight changes in wind speed. The two non-distilling heaters tested were of course unaffected, since in these heaters the fuel is metered into the burner; however such heaters are sensitive to temperature effects, especially when the oil used is of such nature that it thins rapidly on being warmed, for example, oils A, B, C, and L in figure 11 (see also table 6). The oil burning heaters have characteristic burning rate curves, a few of which are shown in figure 2 .

It should be emphasized that in the tests in which data for these curves were obtained the only draft adjustments were made immediately after lighting. Also no fuel was added during test. Frequent regulation is essential in practice to secure the desired results. Generally the adjustment will be for a low burning rate at lighting when only a little heat is needed. Towards morning when the temperature may tend to go very low a much higher burning rate may be required; this would necessitate re-regulation and, in lard-pail and briquet heaters, re-fueling, or lighting of reserve heaters. It should be noted that all briquet type heaters tested were lighted at the top. Bottom lighting causes the fuel to burn out in a shorter time.

The peaks that are found on curves 3 and 8 (fig. 2 ) at points about one hour after lighting are evidently caused by the warming of the oil and consequent more rapid vaporization. The later falling off of the burning rates is no doubt due to the oil level becoming lower in the reservoirs and to the fact that the more volatile portions of the fuel burn first leaving the heavier, more slowly vaporizing portions. In some heaters clogging with soot undoubtedly tends to slow the rate of burning.

Most of the deviations from smooth curves are due to the effects of variations in wind speed and air temperature; some may be the result of errors in the readings. It will be noted (fig. 2) that the burning rates of briquet type heaters are often much more erratic than those of the oil burners. The method and skill used in kindling and in lighting and also the character of the material used for kindling 
have a considerable effect upon the promptness with which the heater will come up to its maximum burning rate for a given adjustment. Curves 9 and $9^{\prime}$ show variations that may be expected. Curve $9^{\prime}$ is a typical case of slow starting which may be caused by using too little or poor quality kindling, by improper placing of the kindling, or by unskillful application of the oil from the lighting torch. For briquet heaters two jute balls (fig. 3) filled with paraffin and placed under the top layer of briquets proved to be very satisfactory kindling. No deterioration of the kindling would oceur even if the unlighted heater were left standing several years. Pieces of old automobile casing were found to serve well except for the smoke and odor. A quart of dried peach pits similarly placed was also satisfactory. Short pieces of seasoned wood thoroughly soaked with refuse crank-case oil served the purpose though they were less pleasant to handle.

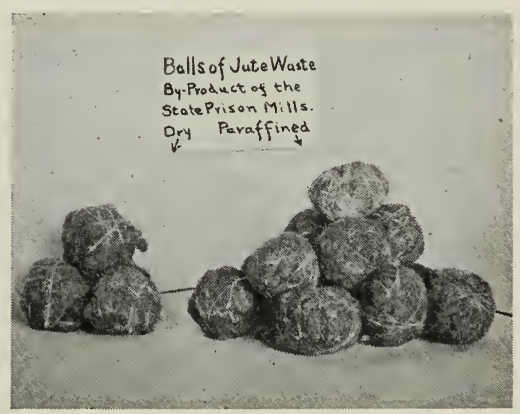

Fig. 3.-A satisfactory kindling for briquets. Balls of jute waste $2 \frac{1}{2}$ inches in diameter dipped into melted paraffin. Two are placed under the top layer of briquets. They are unaffected by weather or time and start readily when lighted with fuel from a lighting torch.

Another factor that influences greatly the burning rate of a given heater under given conditions is the volatility of the fuel used. If light oil is used the rate of burning will be more rapid.

In these tests the briquet heaters burned up to nearly 5 pounds of fuel per hour (table 4), and the oil burning heaters up to nearly 15 pounds per hour (table 5). It is understood, of course, that the oil burning heaters other than lard-pail type could have been adjusted so as to consume at considerably more than the highest rates given in the summaries, but in general it would have been at the penalty of higher upward velocities and higher radiation rates. Also such excessively high adjustment would have greatly increased the smoke nuisance. 


\section{FUEL-TO-HEAT CONVERSION EFFICIENCY}

To find out how efficiently the several heaters converted fuel into heat it was necessary to analyze the hot gases arising from them to find the per cent of carbon monoxide gas and to determine the weight of smoke (carbon) per unit volume of the hot gases. It was found necessary to take the samples of the gases just above the tip of the flame. If taken too low, considerable amounts of unburned oily vapors and much larger amounts of carbon would be drawn. If taken too high, there was greater danger of taking some fresh air. Hence good results could be obtained only when the wind was nearly still. Especially sensitive apparatus was used to determine the per cent of carbon monoxide. This was in no case found to be greater than fivehundredths of one per cent even when the gas sample had been taken a little too close to the flame. The heat loss represented by the unburned carbon in the smoke of some of the smokiest heaters was only about one-tenth of one per cent of the heat value of the fuel used. We must conclude therefore that the fuel-to-heat conversion efficiency of all the heaters tested was practically 100 per cent. That is to say, the heaters tested got out of the fuel used practically all the heat there was in it. This takes no account of fuel left unburned in the reservoirs, or else assumes that the drafts in distilling type heaters are opened sufficiently at the last to burn out completely the asphaltic residues. In practice this latter would not usually be done on account of the danger of warping and of burning holes in the bottoms of the reservoirs. In the tests here reported only fresh oil was used. In practice it is customary to add enough fresh oil to refill the partially emptied reservoirs after each night's use. Thus the heavier residues may accumulate. Cases have been reported where from this cause near the close of a long period of freezing weather lighting became very difficult and large quantities of tarry or asphaltic matter were left when the fires would no longer burn with the ordinary draft regulations. (For further discussion of smoke measurements see p. 17, and of fuels, p. 27.)

\section{RADIATION FROM HEATERS}

Heat that passes out in straight lines from a hot object as a center does not appreciably warm the air or other medium through which it passes. It is only when the heat ray strikes some opaque object and is absorbed that it is able to warm the air in the neighborhood. For these reasons that portion of the heat that is radiated upwards 
from an orchard heater is largely lost to the sky. Whatever heat is radiated along lines that fall below the horizontal will of course be absorbed by the soil and be effective in warming the air. Also any rays that strike leaves, twigs, branches, and stems of trees would be saved. Hence more of the radiant heat would be lost in a deciduous orchard than in a citrus grove.

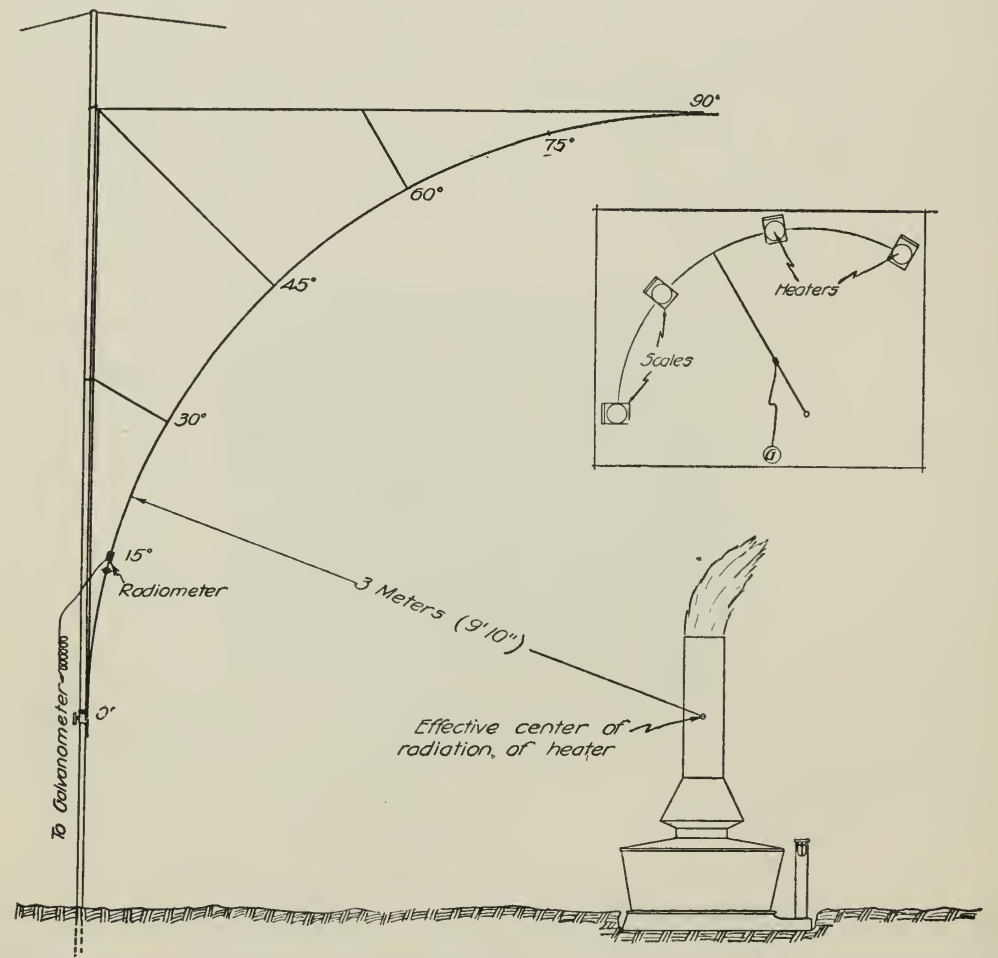

Fig. 4.-Apparatus for measuring radiation from orchard heaters. Four heaters placed on scales set in an are of a circle were tested in succession by swinging the radiometer from one to another. Readings were taken at seven positions from $0^{\circ}$ angle (horizontal) up to $90^{\circ}$ angle (vertical). The radiometer was connected electrically to a sensitive galvanometer in the instrument shelter.

The higher the temperature of the hot gases and of the heater surfaces the greater will be the radiation loss. Evidently the radiation rate will vary as gas and surface temperatures change. A flaming heater radiates more than one that is too cool to emit light.

Apparatus was devised for measuring the heat radiated above the horizontal plane through the effective radiation centers of the several heaters (fig. 4). The total heat radiated upward was in some cases nearly 5 per cent of the total heat in the fuel burned (see summaries of night tests, tables 4 and 5). 
A number of attempts were made to reduce the radiation loss by the use of screens of various shapes. All of these proved effective in some degree. The most practicable form of radiation screen found (though far from being the most effective) was a simple flat baffle plate placed a few inches above the stack. Figure 5 shows graphically the effect.

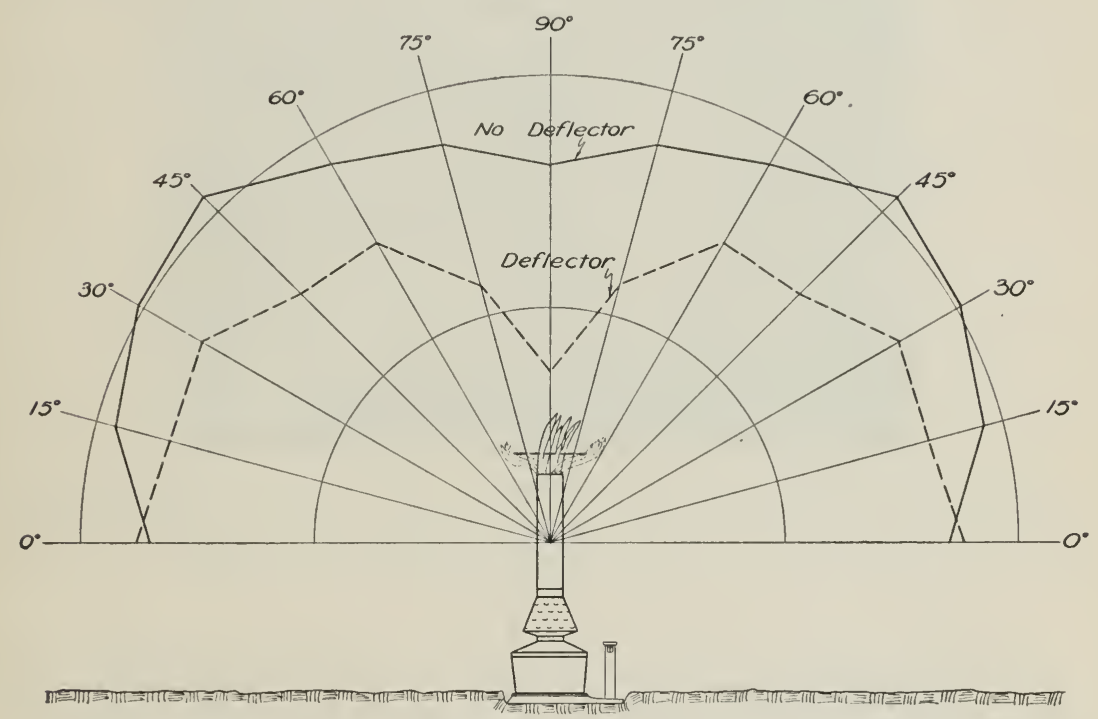

Fig. 5.-How a deflector affects radiation to the sky. Distances out from center are proportional to the intensity of radiation. The space between the two curves indicates roughly the heat saved by the use of an 18-inch square deflector placed on a Scheu Jumbo Cone Louvre heater burning 10.63 pounds of No. 1 oil per hour.

\section{UPWARD VELOCITY OF THE WARM GASES}

The warm gases rising from an orchard heater should not rise too rapidly or they may not spread out horizontally and come to rest at a sufficiently low level. If shot out at high velocity and high temperature they may instead "penetrate the temperature-equilibrium ceiling" above the orchard and in some degree become ineffective as far as warming the orchard is concerned. Measurement of the upward velocity of the hot gases was accomplished by use of a ligh-temperature anemometer especially designed and built for the purpose. Calibration was made to enable interpretation of its readings in terms of feet per second. A further study is to be made to find out how high gases starting at 14 feet per second will normally rise in an orchard. 


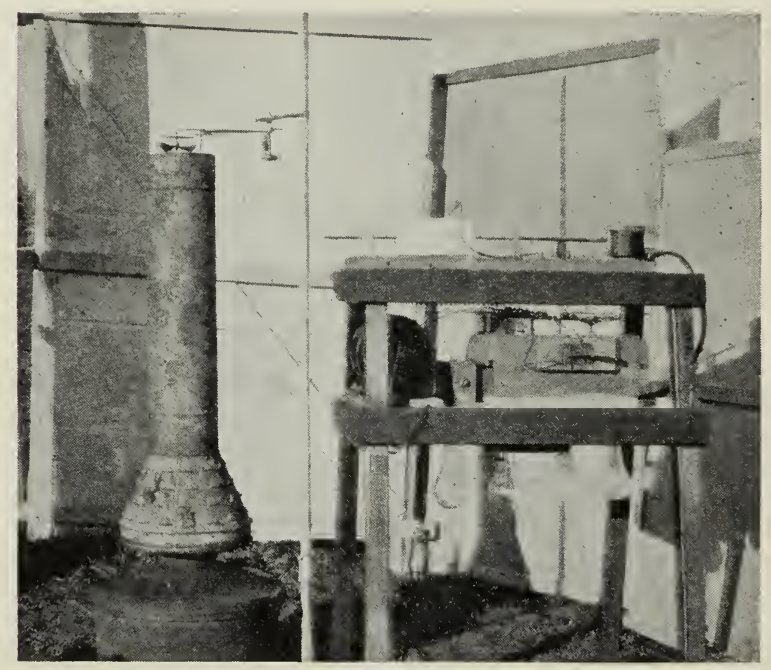

Fig. 6.-High-temperature anemometer as set ready for use in out-of-doors tests. This measures the upward velocity of the hot gases. The revolutions are recorded electrically on the chronograph roll seen on the right.

Figure 6 shows the high-temperature anemometer in position for use in a field laboratory test. In the field tests the anemometer was placed in line with the center line of the stack and partly within the top to lessen wind effects. In the indoor tests it was placed as in figure 7 , in the region of highest velocity of the gases. In a few cases,

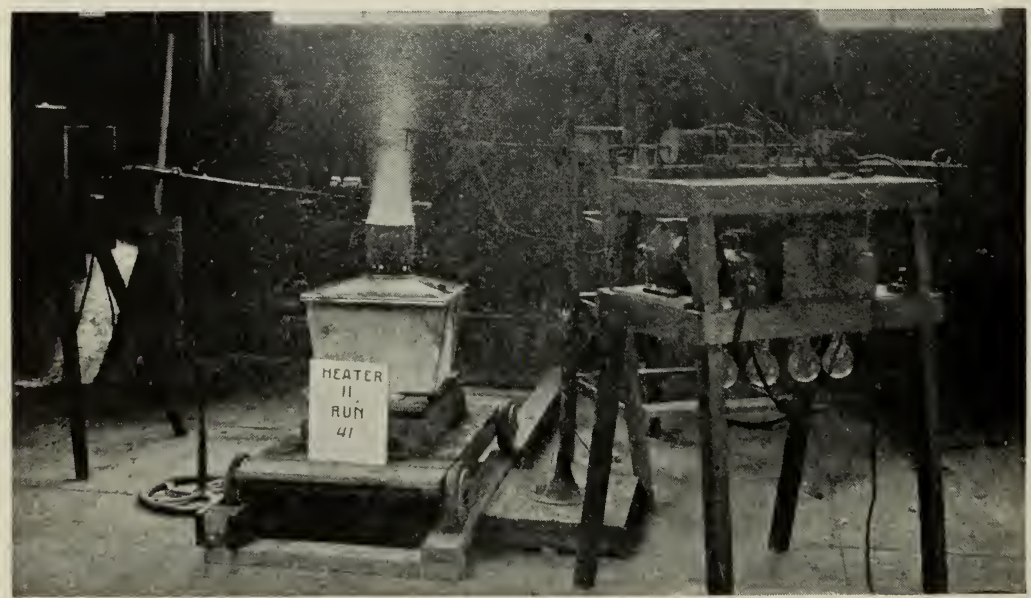

Fig. 7.-Anemometer placing in indoors tests. The region of highest velocity is generally found at about two diameters distance above the stack in still air. 
especially of low or medium stack heaters, slightly higher velocities (and sometimes higher gas temperatures also) were found at low burning rate adjustment than at higher adjustment in the same heater. These apparent discrepancies were in general due to the fact that the column of rising gases in some cases did not fill the whole area of the stack but was concentrated in a portion of the space. As will be seen in the summaries, tables $2,3,4$, and 5 , the velocities range from less than 2.5 feet per second (below which the anemometer would not run satisfactorily) to about 5 feet per second for briquet burning heaters, and from the same low limit up to about 14 feet per second for oil burners.

The same flat baffle plate that was found practicable to reduce radiation to the sky may be used satisfactorily above many of the heaters now in use. Its use will stop the rapid rise of a concentrated stream of high temperature gases and send them out horizontally at greatly reduced speed, at the same time mixing them more effectively with the cold air. It was found that the upward velocity of the gases from heaters Nos. 2 and 17 was less than 2.5 feet per second when the regular baffles were in place but about 8 and 6 feet per second, respectively, when the baffles were removed.

\section{TEMPERATURE OF GASES AND HEATER SURFACES}

It was found very simple and easy to measure these temperatures by use of electrical pyrometers designed to work at the temperatures involved. Measurement was made just at the top of the stacks. Luminous flames were found very hot, in some cases running about $1400^{\circ} \mathrm{F}$. The temperatures of the heater surfaces were found to vary considerably, depending upon the distribution of the fires inside. In briquet burning heaters lighted at the top large and very irregular variations were found. Hot spots develop and move as the fire spreads through the fuel. As before indicated, excessively high surface temperatures are undesirable because they tend to increase radiation losses. They also tend to cause rapid destruction of the heaters.

\section{SMOKE FROM ORCHARD HEATERS}

While, as before indicated (under "Efficiency," p. 13), the smoke from orchard heaters does not represent an appreciable heat loss, it is nevertheless a great nuisance to the fruit grower and his helpers and to everybody else within its range, and does not itself appreciably lessen the danger of frost damage. ${ }^{(3)}$ 
In the study of smoke two things were sought: (1) to weigh the smoke in a given volume of the gases and, (2) to secure a visible record by which relative smokiness might be compared. Some difficulties were encountered, but satisfactory methods and apparatus were finally evolved. The weights of smoke were found to be exceedingly small (summaries, tables 2, 3, 4 and 5).

TABLE 2

Summary of Daytime Tests Briquet Burning Heaters*

\begin{tabular}{|c|c|c|c|c|c|c|c|c|c|}
\hline \multirow{2}{*}{ No. } & \multirow{2}{*}{ Heater } & \multirow{2}{*}{$\begin{array}{c}\text { Fuel } \\
\text { charge, } \\
\text { pounds }\end{array}$} & \multirow{2}{*}{$\begin{array}{l}\text { Fuel, } \\
\text { pounds } \\
\text { per hr. }\end{array}$} & \multicolumn{2}{|c|}{$\begin{array}{l}\text { Time since } \\
\text { lighting, }\end{array}$} & \multirow{2}{*}{$\begin{array}{l}\text { Heat } \\
\text { in fuel } \\
\text { B.t.u. } \\
\text { per hr. }\end{array}$} & \multirow{2}{*}{$\begin{array}{l}\text { Maximum } \\
\text { upward } \\
\text { velocity } \\
\text { feet per } \\
\text { second }\end{array}$} & \multirow{2}{*}{$\begin{array}{l}\text { Temper- } \\
\text { ature of } \\
\text { gasest, } \\
\text { degrees } \\
\text { F. }\end{array}$} & \multirow{2}{*}{$\begin{array}{c}\text { Smoke, } \\
\text { pound } \\
\text { per } 1000 \\
\text { cu. ft. } \\
\text { gas }\end{array}$} \\
\hline & & & & Hr. & Min. & & & & \\
\hline 1 & Pomona................ & $\begin{array}{l}24 \\
20 \\
17\end{array}$ & $\begin{array}{l}2.94 \\
2.81 \\
1.41\end{array}$ & $\begin{array}{l}1 \\
2 \\
5\end{array}$ & $\begin{array}{l}00 \\
00 \\
20\end{array}$ & $\begin{array}{l}39,590 \\
37,839 \\
18,987\end{array}$ & $\begin{array}{l}4.7 \\
4.4 \\
2.7\end{array}$ & $\begin{array}{l}690 \\
305 \\
485\end{array}$ & $\begin{array}{l}.0085 \\
.0062 \\
\text { Clear }\end{array}$ \\
\hline 9 & Diamond...... & $\begin{array}{l}19 \\
13\end{array}$ & $\begin{array}{l}3.44 \\
2.06\end{array}$ & $\begin{array}{l}1 \\
4\end{array}$ & $\begin{array}{l}55 \\
17\end{array}$ & $\begin{array}{l}35,281 \\
27,740\end{array}$ & $\begin{array}{l}2.6 \\
3.0\end{array}$ & $\begin{array}{l}600 \\
415\end{array}$ & $\begin{array}{l}\text { Trace } \\
\text { Clear }\end{array}$ \\
\hline 13 & Karr & 22 & 4.31 & 2 & 00 & 58,038 & 5.1 & 460 & .0145 \\
\hline 14 & Jessen, large....... & & & No & day & run & & & \\
\hline 15 & Jessen, medium & & & No & day & run & & & \\
\hline 16 & Jessen, small & $\begin{array}{l}18 \\
12\end{array}$ & $\begin{array}{l}3.28 \\
1.78\end{array}$ & $\begin{array}{l}1 \\
3\end{array}$ & $\begin{array}{l}30 \\
55\end{array}$ & $\begin{array}{l}44,169 \\
17,477\end{array}$ & $\begin{array}{l}\text { Less than } 2.5 \ddagger \\
\text { Less than } 2.5\end{array}$ & $\begin{array}{l}645 \\
335\end{array}$ & $\begin{array}{l}.0044 \\
\text { Trace }\end{array}$ \\
\hline
\end{tabular}

* All tests made indoors with No. 3 briquets (see table 7).

${ }^{2}$ Product of pounds fuel per hour by heat content per pound as obtained by bomb calorimeter.

'Measured at region of maximum velocity.

$\dagger$ Measured at top of stack.

$\ddagger$ Regular lid in place. Without lid, 4.8.

For making a visible record of relative smokiness of all the heaters the same volume of gases for each, taken from just above the tip of the flame, was passed at the same rate through a circle 3 inches in diameter in the center of a 5-inch square of white felt. For the speed at which the gases passed through, the felt used made a practically perfect filter. Because of its long bill or tube (for cooling the gases before they reached the felt) the device in which the square of felt was clamped was termed the "smoke mosquito." Figure 8 shows it in use in an indoor test. The record of smoke in the out-of-doors tests is shown in figure 9 and in tables 4 and 5 . Series of records were taken on two briquet heaters (Nos. 1 and 14, fig. 9) to show the behavior with the passage of time. Where in the summaries (tables $2,3,4$ and 5 ) the 


\section{TABLE 3}

Summary of Daytime Tests, Oil Burning Heaters*

\begin{tabular}{|c|c|c|c|c|c|c|c|}
\hline No. & Name and type & $\begin{array}{c}\text { Fuel } \\
\text { charge, } \\
\text { pounds, } \\
\text { approx. }\end{array}$ & $\begin{array}{l}\text { Fuel, } \\
\text { pounds } \\
\text { per } \\
\text { hour }\end{array}$ & $\begin{array}{l}\text { Heat } \\
\text { in fuel } \\
\text { B.t.u. } \\
\text { per hr. }\end{array}$ & $\begin{array}{l}\text { Maximum } \\
\text { upward } \\
\text { velocity, } \\
\text { ft. per sec. }\end{array}$ & $\begin{array}{c}\text { Tempera- } \\
\text { ture of } \\
\text { gases, } \\
\text { F. }\end{array}$ & $\begin{array}{l}\text { Smoke, } \\
\text { pound } \\
\text { per } 1000 \\
\text { cu. ft. gas }\end{array}$ \\
\hline 2 & Kittle, non-distilling...................... & 36 & 3.38 & 66,748 & Less than 2.5 & 665 & $\begin{array}{l}\text { Trace } \dagger \\
.0053 \dagger \\
.0053 \dagger \\
.0053\end{array}$ \\
\hline 17 & Low delivery, non-distilling. & 44 & 1.97 & 38,904 & Less than 2.5 & 460 & $\begin{array}{l}.0107 \\
\text { Trace }\end{array}$ \\
\hline 17 & Low delivery, non-distilling.. & 41 & 3.72 & 73,463 & Less than 2.5 & 715 & $\begin{array}{l}\text { Trace } \\
.0044\end{array}$ \\
\hline 3 & $\begin{array}{r}\text { Scheu Jumbo Cone Louvre, } \\
\text { distilling...................................... }\end{array}$ & 32 & 6.67 & 131,719 & 10.9 & 955 & $\begin{array}{l}\text { Clear } \\
\text { Clear }\end{array}$ \\
\hline 4 & $\begin{array}{r}\text { Scheu Baby Cone Louvre, } \\
\text { distilling...................................... }\end{array}$ & 31 & 5.44 & 107,429 & 11.8 & 865 & $\begin{array}{l}.0124 \\
.0329\end{array}$ \\
\hline 4 & $\begin{array}{c}\text { Scheu Baby Cone Louvre, } \\
\text { distilling....................................... }\end{array}$ & 30 & 3.00 & 59,244 & 9.7 & 645 & $\begin{array}{l}.0062 \\
\text { Trace }\end{array}$ \\
\hline 5 & 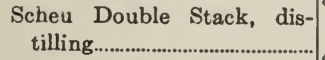 & 35 & 3.56 & 70,303 & 8.0 & 1,060 & $\begin{array}{l}.0062 \\
.0071\end{array}$ \\
\hline 5 & 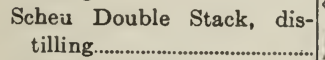 & 34 & 2.91 & 57,467 & 6.9 & 655 & $\begin{array}{l}\text { Trace } \\
\text { Trace }\end{array}$ \\
\hline 6 & Bolton, distilling & 12 & 3.94 & 77,807 & 4.7 & 670 & $\begin{array}{l}.0338 \\
.0373\end{array}$ \\
\hline $6 \mathrm{~s}$ & Bolton, spider on, distilling.... & 11 & 0.85 & 16,786 & Less than 2.5 & 286 & $\begin{array}{l}.0115 \\
.0115\end{array}$ \\
\hline 7 & Troutman, distilling.................... & 8 & 1.56 & 30,807 & 3.5 & $(-\ldots \ldots \ldots \ldots$ & $\begin{array}{l}.0364 \\
.0409\end{array}$ \\
\hline 8 & Canco, distilling................... & $\begin{array}{r}12 \\
10 \\
9\end{array}$ & $\begin{array}{l}5.63 \\
5.83 \\
6.04\end{array}$ & $\begin{array}{l}109,838 \\
115,131 \\
192,779\end{array}$ & $\begin{array}{l}4.8 \\
5.7\end{array}$ & $\begin{array}{r}1,020 \\
940\end{array}$ & $\begin{array}{l}.0364 \\
.0267 \\
.0249\end{array}$ \\
\hline $8 \mathrm{~s}$ & Canco (spider on) distilling.... & 13 & 1.03 & 20,340 & Less than 2.5 & 310 & $\begin{array}{l}.0178 \\
.0187\end{array}$ \\
\hline $10 \mathrm{~A}$ & Dunn, distilling & 24 & 4.25 & 83,929 & 8.0 & 1,420 & $\begin{array}{l}.0275 \\
.0249\end{array}$ \\
\hline $10 \mathrm{C}$ & $\begin{array}{r}\text { Dunn, with } 30^{\circ} \times 6^{\prime} \text { stack, } \\
\text { distilling }\end{array}$ & 22 & 4.50 & 88,866 & 8.8 & 830 & $\begin{array}{l}.0364 \\
.0382\end{array}$ \\
\hline $11 \mathrm{~A}$ & 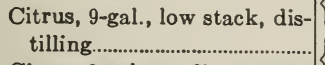 & 31 & 3.09 & 61,021 & 7.7 & 1,160 & $\begin{array}{l}.0151 \\
.0124\end{array}$ \\
\hline $11 \mathrm{~B}$ & 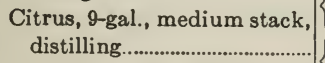 & 29 & 4.98 & 98,345 & 8.1 & 1,125 & $\begin{array}{l}.0187 \\
.0222\end{array}$ \\
\hline $11 \mathrm{C}\}$ & 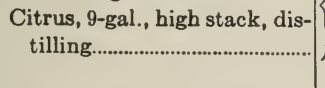 & 25 & 10.78 & 212,883 & 14.1 & 1,140 & $\begin{array}{l}.0293 \\
.0213 \\
.0231\end{array}$ \\
\hline $12 \mathrm{~A}\{$ & 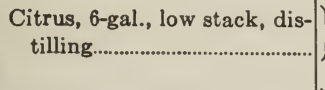 & 34 & 2.69 & 53,122 & 6.0 & 885 & $\begin{array}{l}.0258 \\
.0258 \\
.0258\end{array}$ \\
\hline 12B & 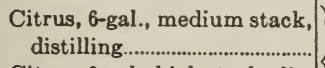 & 31 & 5.0 & 98,740 & 9.8 & 1,160 & $\begin{array}{l}.0187 \\
.0240\end{array}$ \\
\hline $12 \mathrm{C}\}$ & 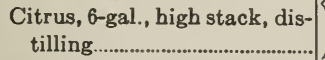 & 28 & 10.0 & 197,480 & 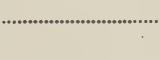 & 1,115 & $\begin{array}{l}.0115 \\
.0142\end{array}$ \\
\hline 18 & Baby Double Stack, distilling & 13 & 3.00 & 59,244 & 4.3 & 1,010 & $\begin{array}{c}\text { Trace } \\
.0178\end{array}$ \\
\hline 18 & Baby Double Stack, distilling & 12 & 1.60 & 31,597 & 6.3 & 1,070 & $\begin{array}{l}\text { Clcar } \\
\text { Clear }\end{array}$ \\
\hline 19 & Citrus Gas Flame, distilling & 22 & 3.94 & 77,807 & 4.0 & 850 & $\begin{array}{l}\text { Trace } \\
\text { Trace }\end{array}$ \\
\hline
\end{tabular}

* All tests made indoors with No. 2 oil (see table 7).

a Product of pounds fuel per hour by heat content per pound of fuel as obtained by bomb calorimeter.

$\dagger$ Determinations of smoke density were sometimes made in duplicate or in triplicate. 


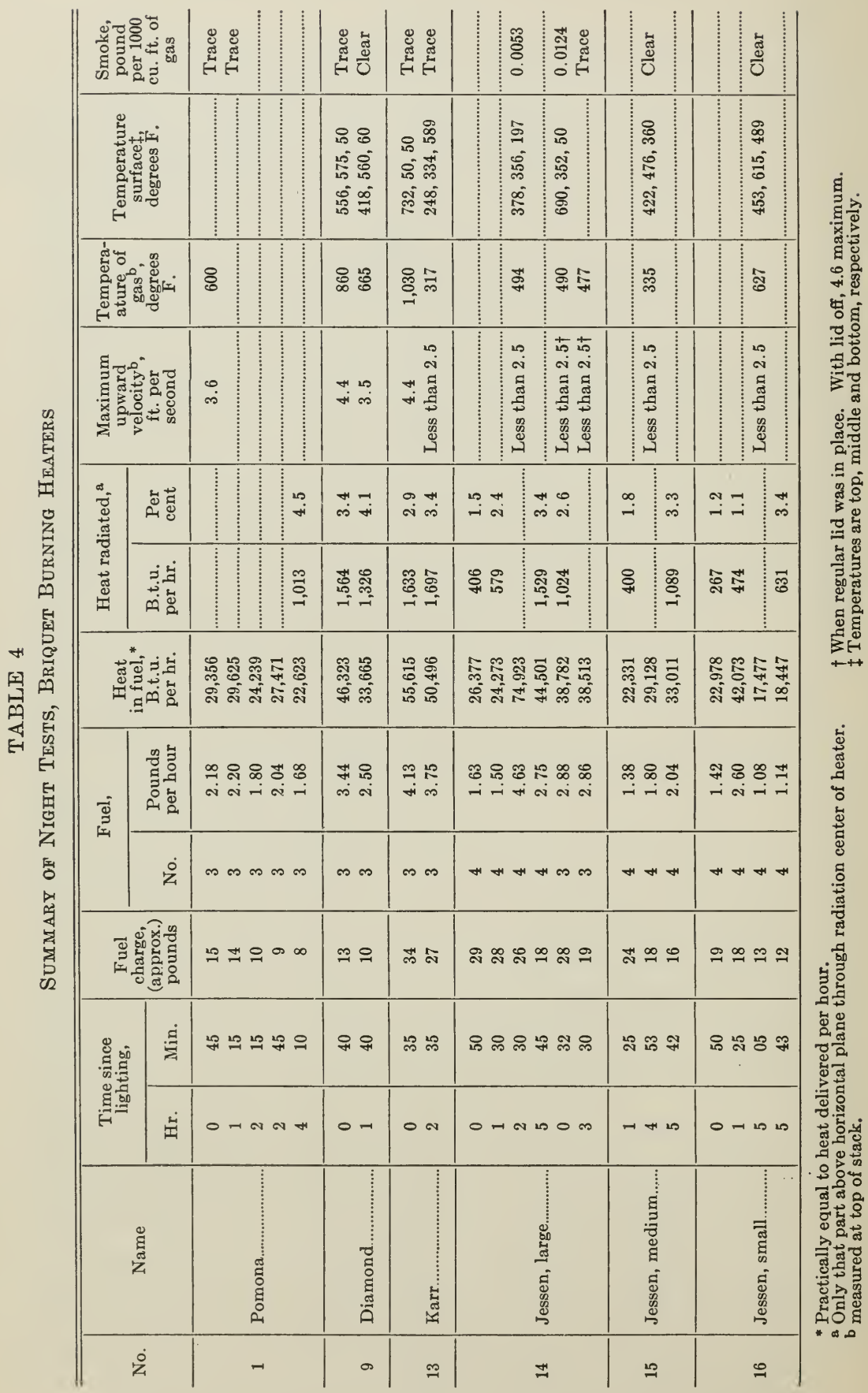




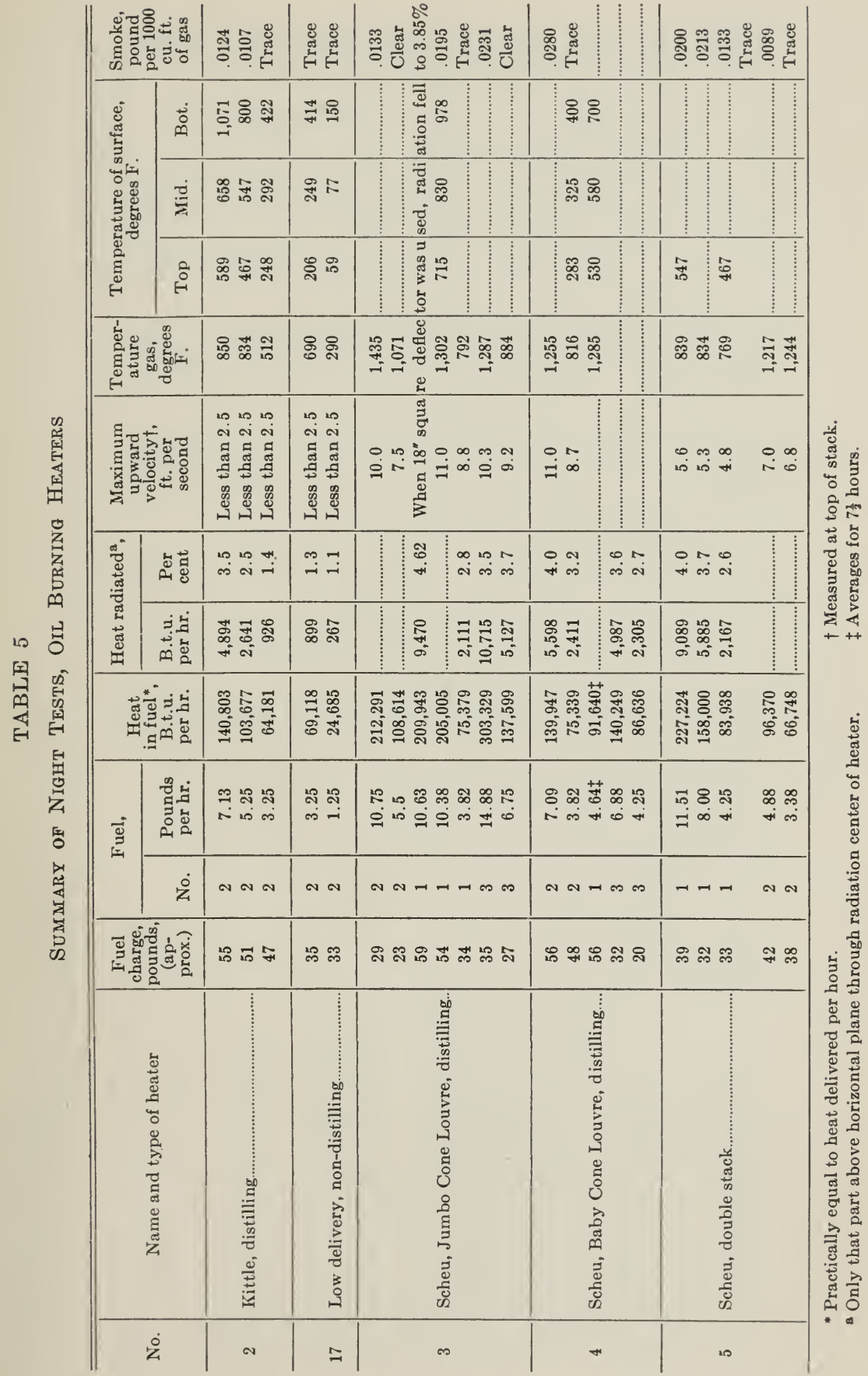




\begin{tabular}{|c|c|c|c|c|c|c|c|c|c|}
\hline \multicolumn{2}{|c|}{ 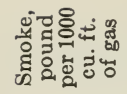 } & 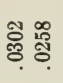 & 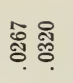 & 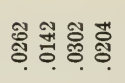 & 츙 융 & 周 & 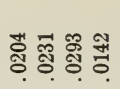 & 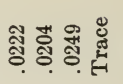 & \\
\hline \multirow{3}{*}{ 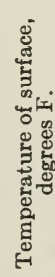 } & 范 & & & & & 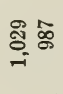 & & & \\
\hline & 羊 & & & & § § & $\stackrel{\infty}{\circ}$ & & \multirow{2}{*}{\multicolumn{2}{|c|}{$\stackrel{2}{4} \underset{\infty}{\infty} \stackrel{\infty}{\infty}$}} \\
\hline & वิ & & & & & ஜ & 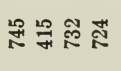 & & \\
\hline \multicolumn{2}{|c|}{ 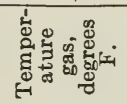 } & $\underset{-\infty}{0}$ & $\mathscr{\infty}_{\infty}^{\infty} \stackrel{0}{0}$ & 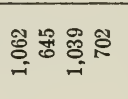 & 等呑 & $\stackrel{2}{=}$ & 兽哭哭哭告 & \multicolumn{2}{|l|}{ 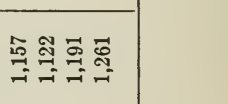 } \\
\hline \multicolumn{2}{|c|}{ 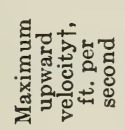 } & 趈 & $\hat{i} \stackrel{\infty}{+}$ & 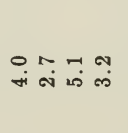 & $\stackrel{ }{N}$ & $\stackrel{\circ}{=} \dot{\circ}$ & 点 & $\stackrel{0}{N} \stackrel{0}{0}$ & \\
\hline \multirow{2}{*}{ 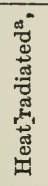 } & 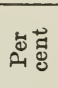 & is & $\stackrel{\sim}{\leftrightarrow}$ & $\stackrel{+}{+\vec{i}}$ & is 20 in & $\because \underset{\text { i }}{7}$ & 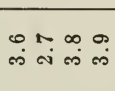 & 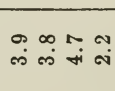 & \\
\hline & 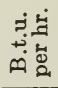 & 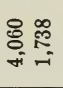 & 芦 & 党 & 总 & 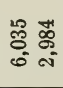 & 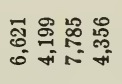 & \multicolumn{2}{|l|}{ 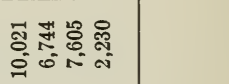 } \\
\hline \multicolumn{2}{|c|}{ 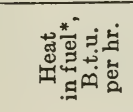 } & 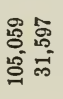 & 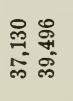 & 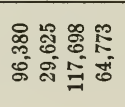 & 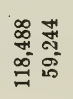 & 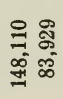 & 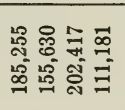 & 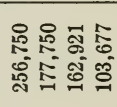 & 岕 \\
\hline \multirow{2}{*}{ 离 } & 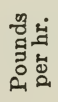 & 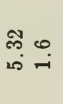 & $\begin{array}{l}\infty \\
\infty \\
i \\
-i \\
i\end{array}$ & 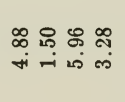 & $\begin{array}{l}88 \\
0 \text { in }\end{array}$ & 虽 & 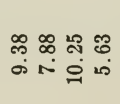 & 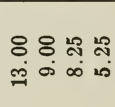 & 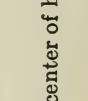 \\
\hline & $\dot{\mathrm{z}}$ & $N \sim$ & $\Rightarrow \sim$ & 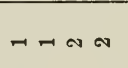 & $\sim N$ & $\sim \sim$ & $\pi \rightarrow a n$ & 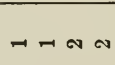 & \\
\hline \multicolumn{2}{|c|}{ 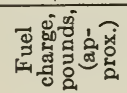 } & $\infty$ 윽 & $0 \infty$ & $\sim \propto$ & $F \stackrel{F}{\circ}$ & ผొ ले & 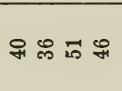 & $\vec{~}$ & 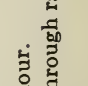 \\
\hline & 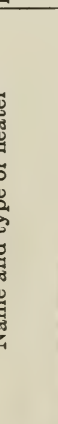 & 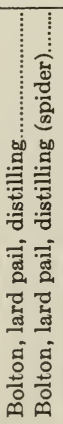 & 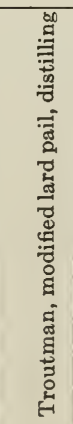 & 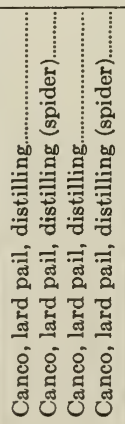 & 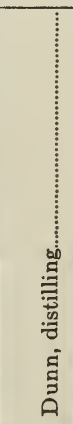 & 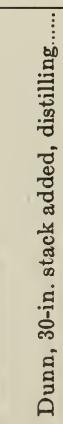 & 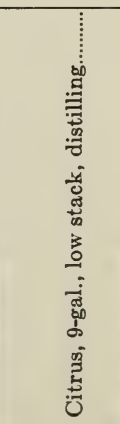 & 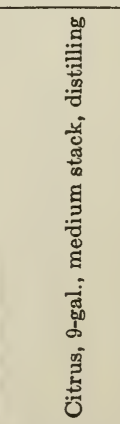 & 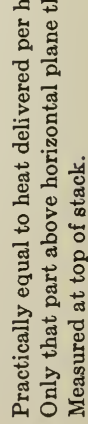 \\
\hline & & 08 & $n$ & $\infty ळ \infty \infty$ & త્ડ & ర્త & 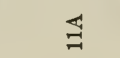 & $\stackrel{\mathscr{a}}{\exists}$ & \\
\hline
\end{tabular}




\begin{tabular}{|c|c|c|c|c|c|c|c|c|}
\hline \multicolumn{2}{|c|}{ 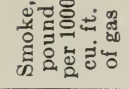 } & 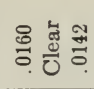 & 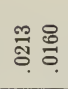 & 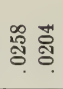 & 궁. & 芯芯 & 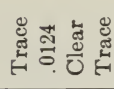 & \\
\hline \multirow{3}{*}{ 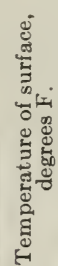 } & लें & œ & & & & $\infty$ & 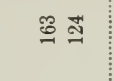 & \\
\hline & 롤 & 路嵒 & & & & $\infty \Xi$ & 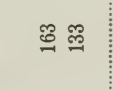 & \\
\hline & $\stackrel{0}{0}$ & 串 & & & & $\stackrel{\infty}{\stackrel{\infty}{\sim}}$ & $\stackrel{\infty}{\infty} \stackrel{\infty}{\stackrel{\infty}{N}}$ & \\
\hline \multicolumn{2}{|c|}{ 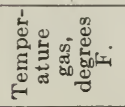 } & $\underset{-1}{\mathbb{N}}$ & 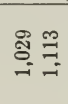 & 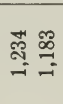 & 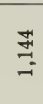 & $\underset{-\infty}{\infty} \underset{-\infty}{\infty}$ & ర్ల & \\
\hline \multicolumn{2}{|c|}{ 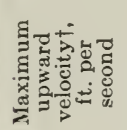 } & 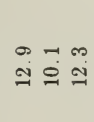 & $\begin{array}{l}\infty \\
+\pi\end{array}$ & $\stackrel{\infty}{\therefore} \vec{\infty}$ & $\stackrel{20}{=}$ & $\underset{+}{\infty} \stackrel{0}{+}$ & $\stackrel{\infty}{\rightarrow} \infty$ & \\
\hline \multirow{2}{*}{ 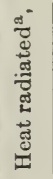 } & 哭 & $\stackrel{0}{\circ}-\vec{i}$ & $\vec{H}$ & $\begin{array}{ll}\sim & 0 \\
\rightarrow & \dot{m}\end{array}$ & $\begin{array}{l}\infty \\
\text { iv }\end{array}$ & $\begin{array}{ll}\infty & 0 \\
i & \text { iv }\end{array}$ & $\ddot{n}$ or & \\
\hline & 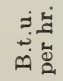 & 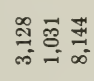 & $\prod_{\substack{7 \\
0}}^{\infty}$ & 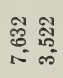 & 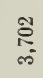 & 㣽 đ్ & 芯芯 & \\
\hline \multicolumn{2}{|c|}{ 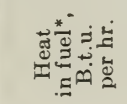 } & 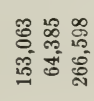 & 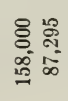 & $\begin{array}{l}\infty \\
\infty \\
\infty \\
\infty \\
0 \\
\infty \\
\infty\end{array}$ & 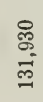 & 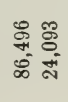 & 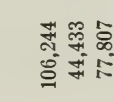 & 岕 \\
\hline \multirow{2}{*}{$\dot{\Phi}$} & 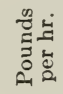 & 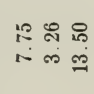 & $\begin{array}{l}8 \text { भ } \\
\infty \\
\infty\end{array}$ & 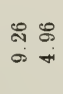 & $\begin{array}{l}\infty \\
0 \\
0\end{array}$ & 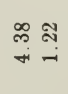 & 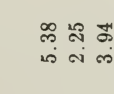 & 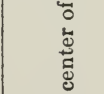 \\
\hline & $\dot{z}$ & $\neg-\infty$ & -- & -7 & - & $N \sim$ & $\sim \sim N$ & \\
\hline \multicolumn{2}{|c|}{ 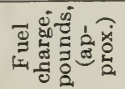 } & $\stackrel{\infty}{\infty} \stackrel{\infty}{\infty}$ & ผึ & $\overrightarrow{\mathrm{N}}$. & $\dddot{2}$ & $\Xi \Xi$ & \& & : \\
\hline \multicolumn{2}{|c|}{ 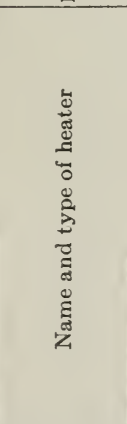 } & 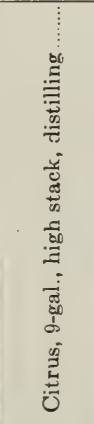 & 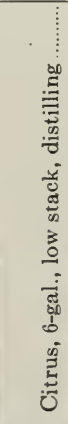 & 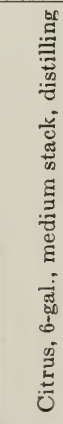 & 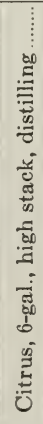 & 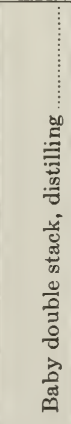 & 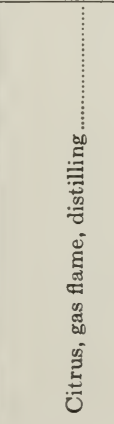 & 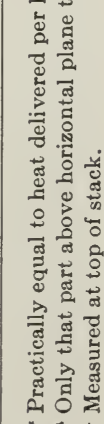 \\
\hline \multicolumn{2}{|c|}{$\dot{z}$} & 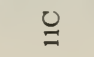 & $\overleftrightarrow{\Xi}$ & సิ & ర్త & $\stackrel{\infty}{\sim}$ & 9 & \\
\hline
\end{tabular}


"smoke, pound per $1000 \mathrm{cu}$. ft. of gas" is given as "clear," no sign of smoke was visible on the felt. Where "trace" is recorded a faint circle was visible but the quantity caught was too small to be weighed.

In the indoors tests a pair of smoke records were taken in the test of each heater. Figure 10 shows these pairs and indicates how closely the smoke records check. The conditions of burning rates, etc., when the indoors smoke records were taken, may be found in tables 2 and 3.

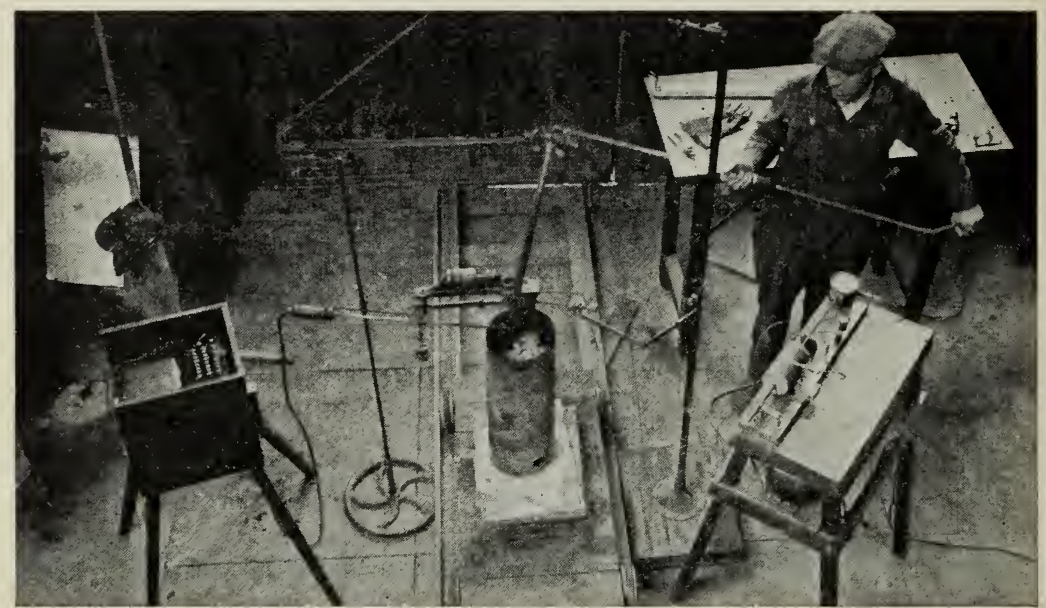

Fig. 8.-The "smoke mosquito"' in use. A measured volume of the gases is drawn from just above the tip of the flame through a square of white felt. Note pyrometer (left) measuring the temperature of the gases.

In practically all the heaters clearer burning was obtained at low burning rates than at high. Nearly all oil burning heaters smoked badly when burned at maximum capacity. A comparative study of all the heaters tested indicated that in some cases a very slight difference in design apparently caused a large difference in smokiness. While absolute smokelessness under all conditions seems not feasible under present conditions of available fuel and equipment, still a great improvements could be made by the elimination, especially in the citrus growing districts, of the lard-pail and all other open type heaters; by redesign of some of the other heaters; by more care in the production of the fuels used; and especially by more care on the part of the user to regulate more frequently and to avoid burning at too high rates. In justice to the user it should be added that poorly designed or constructed heater covers sometimes make it impossible to regulate the burning rate. 


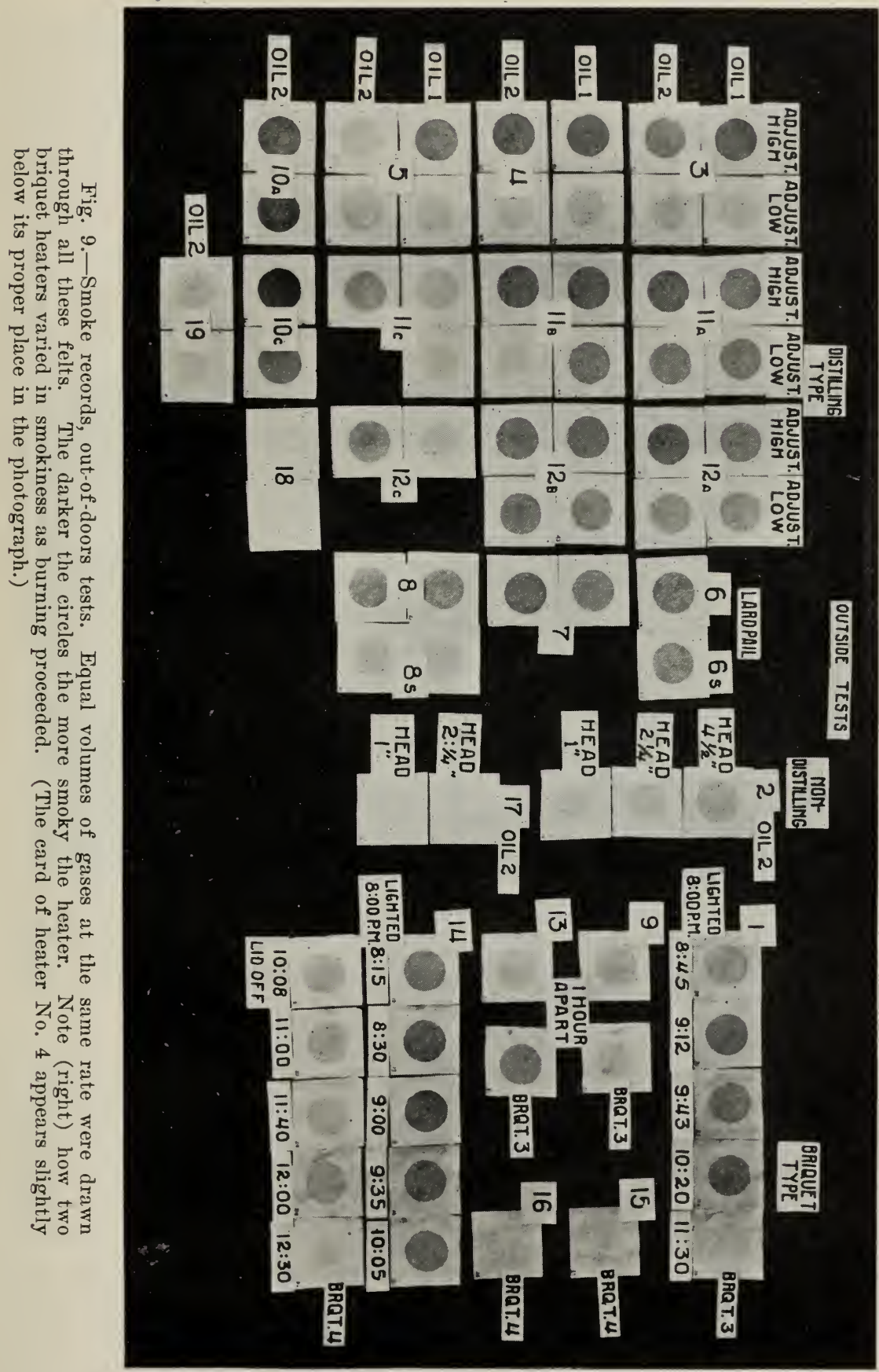




\section{EFFECT OF ORCHARD HEATING ON THE PUBLIC HEALTH}

Considerable complaint has been heard that gaseous products injurious to the health of residents in the citrus growing districts are given off by the heaters. Bronchial and pulmonary affections apparently caused by the smoke or by the gases have been mentioned repeatedly. No exhaustive study of this matter was made but the following facts are determined. Comparison with data given by Henderson, Haggard, Teague, Prince and Wunderlich(2) and by Sayers, Meriwether and Yant ${ }^{(5)}$ of the U. S. Bureau of Mines shows

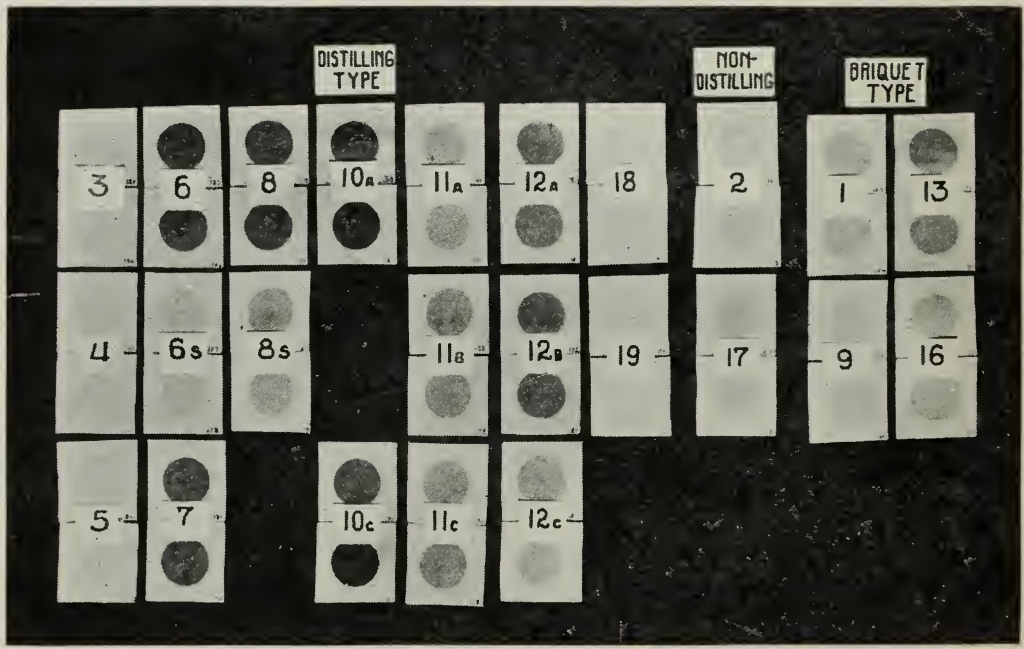

Fig. 10.-Smoke records, indoor tests. At least 2 daytime tests were made on each heater; note the close agreement between the records in each pair. The same fuels (No. 2 oil and No. 3 briquets) were used for all the indoor tests. Wind effects were eliminated in this portion of the test by running indoors. See tables 2 and 3 for rates of fuel consumption, etc.

that the per cent of carbon monoxide given off by orchard heaters is too small to produce any appreciable effect. In fact very much higher concentrations of carbon monoxide are found where automobile traffic is heavy in some of the streets of our cities than would ever be present under the worst conditions in a heated orchard. Some of the fuels sold for orchard heating in this state are rather high in sulphur content (table 7). This sulphur is almost completely ' anged to sulphur dioxide, a gas which, while not dangerous to the same degree as carbon monoxide, is very disagreeable and irritating to the nasal passages, throat and lungs. No method was found to determine 
whether smoke of itself had any effect upon the health. Removal of sulphur from the fuels sold for orchard heating would certainly be highly desirable. Along with this, of course, should go reduction of smoke to a minimum.

\section{FUELS USED IN ORCHARD HEATERS}

Various complaints have been made concerning the oils sold for orchard heating purposes in this state. Several samples of orchard heater oils were secured and subjected to such tests as seemed likely to indicate how satisfactory they might prove in use. Since usually in non-distilling heaters the rate at which the oil will run through a small opening determines the burning rate, tests of viscosity were made on eleven oils (table 6). The California residue test (later

\section{TABLE 6}

Oils Tested for Viscosity and Per Cent of Residue*

\begin{tabular}{|c|c|c|}
\hline No. & Source & $\begin{array}{c}\text { Residue, by } \\
\text { California test, } \\
\text { per cent }\end{array}$ \\
\hline 1 & Same as No. 1 used in the heater tests (Table 6 ).. & 6.83 \\
\hline 2 & Same as No. 2 used in the heater tests (Table 6)....... & 0.201 \\
\hline 3 & Same as No. 3 used in the heater tests (Table 6 ).......... & 0.206 \\
\hline A & Ventura Oil Co., bought at Ventura ............................... & 0.924 \\
\hline $\mathrm{B}$ & 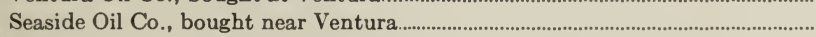 & 0.935 \\
\hline $\mathrm{C}$ & Ventura Oil Co., bought at Fillmore.................................... & 1.206 \\
\hline D & 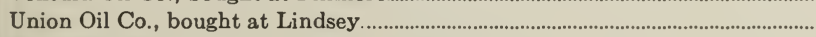 & 0.277 \\
\hline $\mathrm{E}$ & Standard Oil Co., "27+," bought at Lindsey & 0.639 \\
\hline $\mathrm{K}$ & 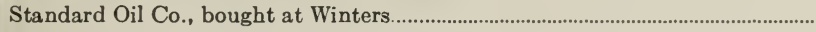 & 0.741 \\
\hline $\mathrm{L}$ & From ranch of P. G. Rhodes, near Winters... & 2.586 \\
\hline $\bar{M}$ & Standard Oil Co., "27+," bought at Los Angeles & $\begin{array}{l}\text { (Sample too } \\
\text { small) }\end{array}$ \\
\hline
\end{tabular}

* All from 1925-26 season supply. The viscosities are given in figure 11 .

described) was also made and the results for some of the oils compared with results obtained for the same oils by use of the regular Conradson carbon test and Holde hard asphalt test. Figure 11 shows graphically the results of the viscosity tests. Evidently the samples that show nearly straight vertical lines (that is, that maintain their free flowing character almost constant from $100^{\circ} \mathrm{F}$ down to well below the freezing temperature of water) would run satisfactorily in a non-distilling type heater. On the other hand an oil like C, B, or L, if lighted and the burning rate properly adjusted at $25^{\circ} \mathrm{F}$, would flow very much faster after the fuel in the reservoir came up to $35^{\circ} \mathrm{F}$ or $40^{\circ} \mathrm{F}$. Oil A was solid at $12^{\circ} \mathrm{F}$ and oil $\mathrm{L}$ at $16^{\circ} \mathrm{F}$. Oil $\mathrm{L}$ would hardly flow at all below $25^{\circ} \mathrm{F}$. 
To study the effect of settling, two samples of oil No. 1 were taken, one from the top and the other from the bottom of a 50 -gallon drum after it had stood undisturbed for three weeks. The bottom oil was found to be $0.5^{\circ}$ Beaumé heavier than the top, but both showed the same viscosity curve as that of the composite sample of oil No. 1. Possibly longer settling might have made a noticeable difference. Also other oils might have behaved differently. Oil No. 1 was chosen principally because it was very dark in color and on being burned left much asphaltic residue.

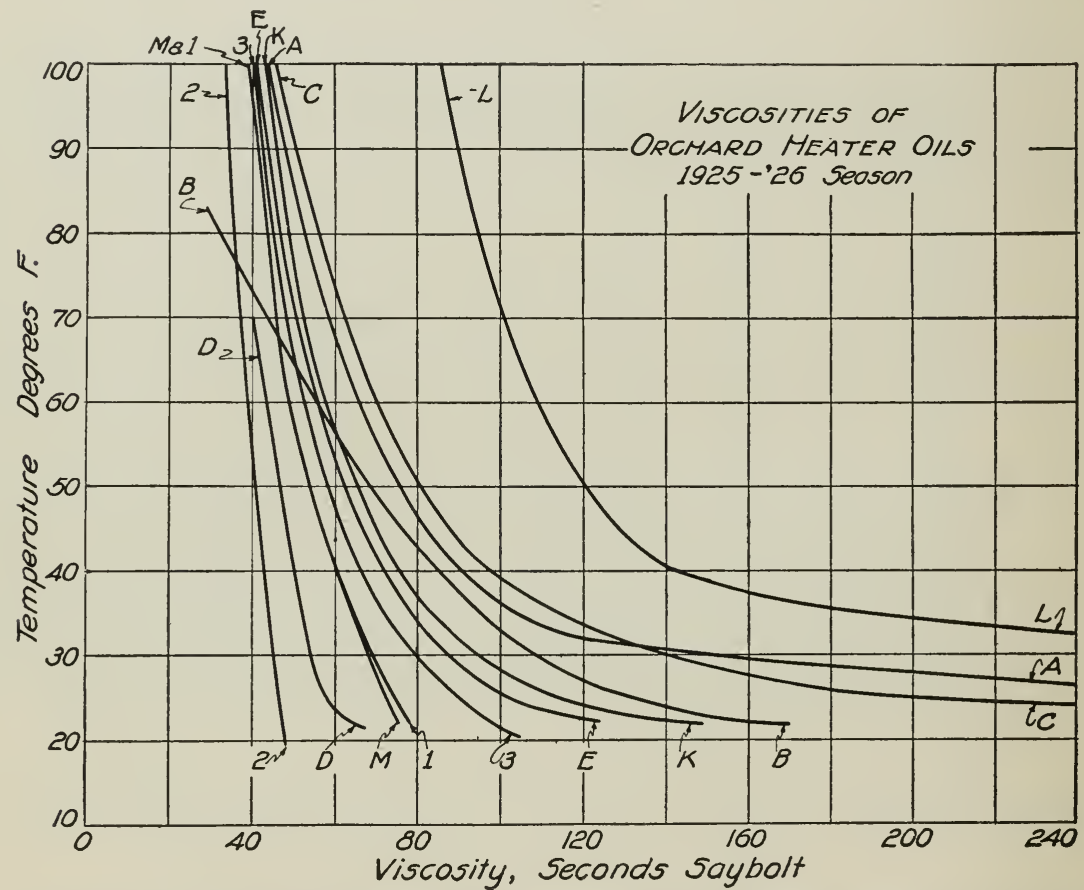

Fig. 11.-As the oils thicken on becoming colder, longer times are required for a standard unit quantity of oil to flow through the standard opening in the Saybolt test apparatus. The straighter lines show oils that thicken less rapidly on cooling. See table 6.

The accumulation of heavy residues in the reservoirs of distilling type heaters and in the burners of the non-distilling type has been a frequent cause of trouble. In extreme cases the heaters would operate very unsatisfactorily or could scarcely be made to burn at all. It seems that these asphaltic residues are not necessarily merely so much asphalt that was present in the original oil, but are probably produced by what the oil chemist calls "cracking of the molecules" of oil when heated. In the "cracking" process a molecule of the oil may be regarded as breaking up and then reassembling it component parts to 
make two new molecules different from each other and from the original molecule. Thus the heat to which the oil in the reservoir is subjected may change some of the oil into two new kinds of oil, one that vaporizes easily and therefore burns readily, and one that is very heavy and hard to vaporize and hence is liable to fail to mix with the oxygen of the air and so be left unburned. Some oils will "crack" much more readily than others.

An attempt was made to find a simple test that would show whether a given oil would "crack" badly or not. The apparatus used consists of a sheet copper burner bowl A (fig. 12), a pedestal B on

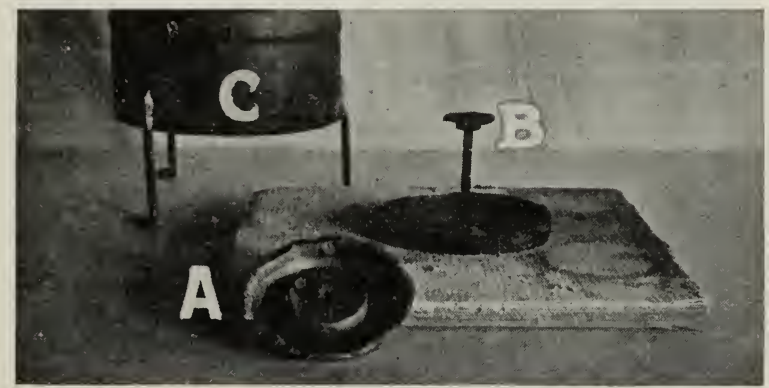

Fig. 12.-California residue test for orchard heater oils. Ten grams of the oil to be tested is placed in bowl A. Bowl is placed on pedestal B and draft pipe $\mathrm{C}$ placed over as in figure 13. Lighting is by an alcohol swab burned under one edge of the bowl. The residue remaining when the fire dies is weighed. See data in tables 6 and 7 .

which to support it, and a draft pipe, C. A 10-gram sample of oil is weighed in the burner bowl, the bowl placed level on the pedestal and the draft pipe placed over it (fig. 13). Lighting is accomplished by the use of a swab soaked in alcohol burned under one edge of the bowl until the fuel ignites. A pasteboard screen to prevent air currents is placed around the apparatus. When the fire dies out the residue is found by weighing the bowl on a sensitive analytical balance. Table 7 gives the results obtained on the oils used in the heater tests and a few other oils, together with results of other standardized tests for oils. It will be noted that there is a rather close parallel between the new California residue test and the Conradson carbon and Holde hard asphalt tests. Since the per cents of residue are considerably larger in the new test than in the Conradson, higher accuracy should be obtained by the California test, with the same degree of care and sensitiveness of instruments. The Conradson test results given were obtained from two companies engaged in conmercial oil testing. It will be noted that the results differ somewhat. The Holde tests were made by the Chemistry Division staff at Davis. 
A very simple test with inexpensive apparatus (fig. 14) may be made by the rancher himself to try orchard heater oils for residue. This is a modification of the California test but is less accurate and gives only a visual instead of a numerical comparison. However, the results obtained are sufficiently definite for all ordinary purposes.

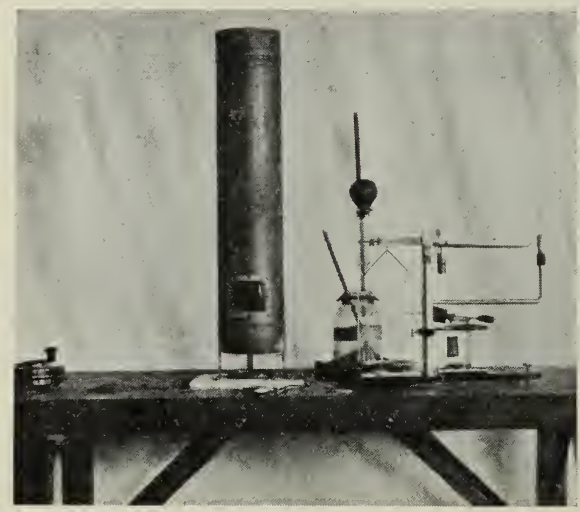

Fig. 13

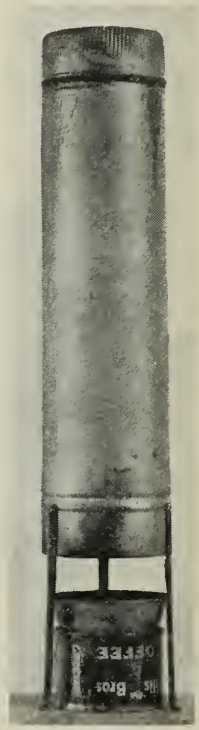

Fig. 14

Fig. 13.-California residue test apparatus (assembled). When in use, a pasteboard screen (not shown) surrounds the apparatus to reduce the effects of air currents. The balance shown is used to weigh the 10 grams of oil. A delicate analytical balance is used for the bowl and residue.

Fig. 14.-Modified form of California residue test apparatus. This enables making a residue test without expensive or delicate apparatus. Half-pint samples of the oils are burned in small tin pans and the residues compared.

Equal volumes ( $1 / 2$ pint) or equal weights $(1 / 2 \mathrm{lb}$.) are taken of the several oils to be tested. Instead of the small copper burner A of figure 12, an ordinary tin pan 51/4 inches inside diameter at the top, $41 / 2$ inches at the bottom and $1 \frac{1}{2}$ inches deep is used. It is well to have as many pans as there are oils to be tested, so that the results may be kept for comparison. An empty tomato can placed bottom end up may be used as a pedestal. The draft tube is not necessary. The oil may be lighted by placing a 2-inch diameter asbestos swab soaked in torch oil (gasoline and kerosene equal parts) under an edge of the pan. If preferred the pan of oil may be heated on top of a stove until it will ignite readily when a lighted match is applied. 

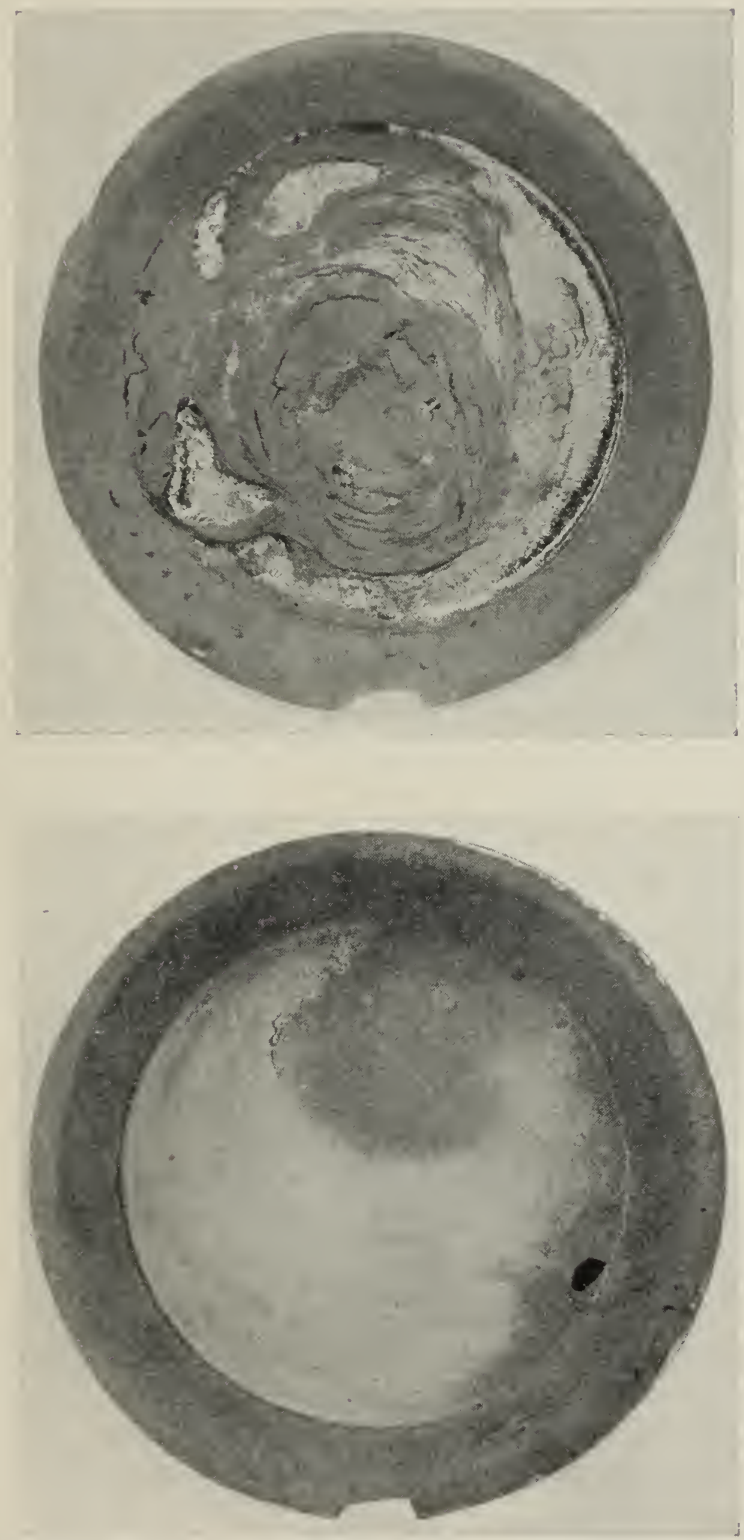

Fig. 15.-Residues from orchard heater oils obtained by use of the apparatus shown in figure 14. Upper, oil No. 1 unsatisfactory; lower, oil No. 2 more satisfactory. 
After lighting, a screen to keep off air draughts should be placed around if the test is made out-of-doors. A carton about 2 feet square and 3 feet high from which the top and bottom have been removed makes a satisfactory screen.

An unsatisfactory oil will leave a residue that is very noticeable though it may weigh less than half an ounce. Usually such a residue will consist of two parts, a thin layer of black, shiny, asphaltic material on the bottom of the pan, and above it a hard, flaky crust consisting mostly of carbon. A satisfactory oil will have no noticeable asphaltic residue and very little of the crusted carbon.

Since the temperature of the pan and contents during the burning determines in a large measure how much residue will be left, it is essential that all the conditions that might affect this temperature should be alike in all tests, if the results are to be compared. This refers especially to the method of lighting and the level placing on the pedestal. Using an asbestos pad between the burner pan and the pedestal in some of the tests and not in the rest, would make the results of doubtful value. Differences of $5^{\circ} \mathrm{F}$ or $10^{\circ} \mathrm{F}$ in the air temperatures when the tests are run will not appreciably affect the results. Figure 15 shows the residues obtained by this test on oils Nos. 1 and 2 (for other data of these oils see table 7). Oil No. 1 produced quite a drip of asphaltic material from the burners of the non-distilling type heaters tested. At intervals the crusted carbon left in the burners by this oil had to be removed. Oil No. 2 burned much more satisfactorily. The briquets used were in general satisfactory. The sulphur fumes were noticeably worse from the coal dust briquets as would be expected from the high sulphur content (table 7 ). The relatively large ash residues from the coal dust briquets sometimes partially clogged the grates and so reduced the burning rates. The coke and carbon briquets used had less sulphur and left no noticeable ash. They were however less satisfactory to handle because of their tendency to blacken anything they touched and to break into pieces.

Comparison of California residue test results with specific gravities (table 7 ) shows that the latter do not give any indication of the probable behavior of an oil with respect to asphaltic residue.

It was found that the asphaltic residues from some oils collected in and under the burners of the non-distilling heaters tested. Sometimes these residues spread over the ground around the heater. With some oils at certain adjustments the residues burned out automatically at intervals or could be made to burn out without apparent harm to the heater by applying a little fuel from the lighting torch to the base of the burner. The residues resulting from "cracking" of the fuel and 


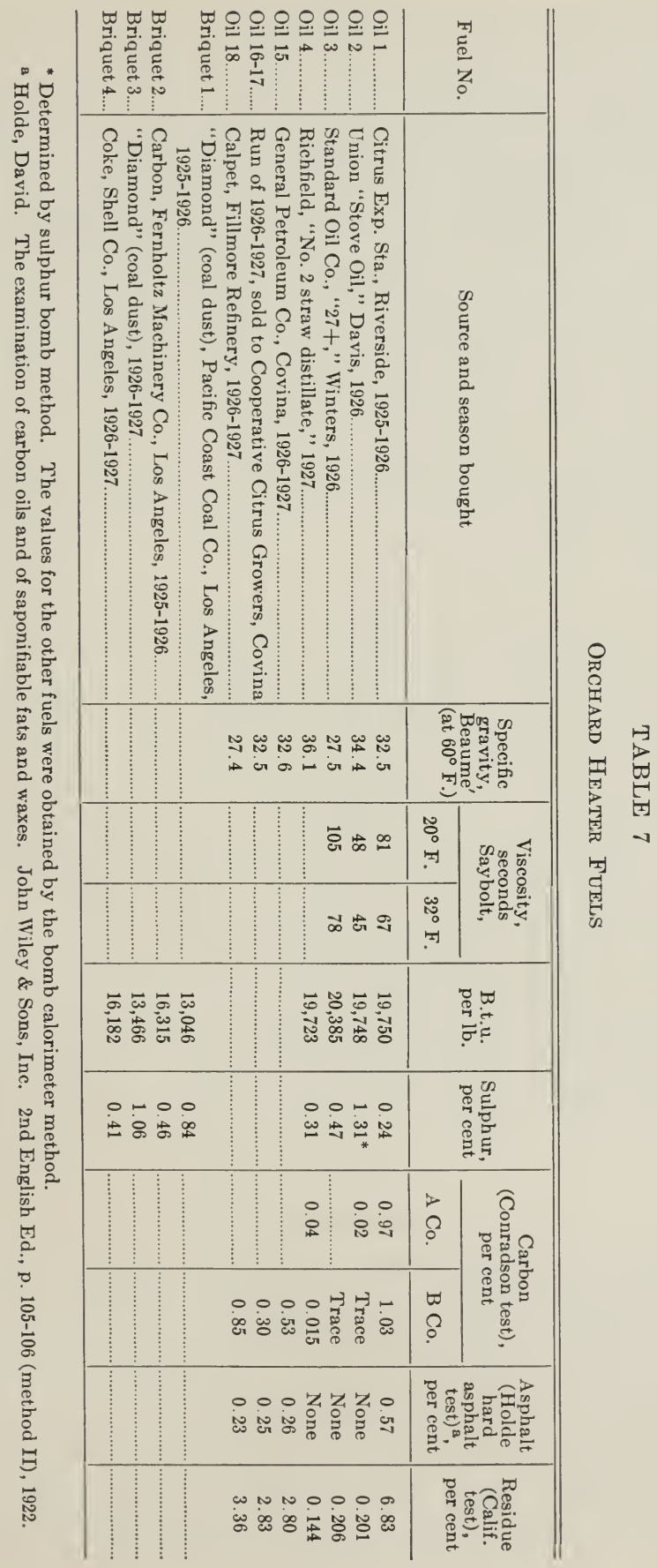


from droppings of soot that accumulated in the reservoirs of the distilling heaters tested could be burned out in many cases by opening the drafts wide. Very high temperatures in the reservoirs would result. Whether this would rapidly destroy the heaters by burning out the bottoms was not determined by these tests. Growers report that reservoirs frequently burn through at the bottom of the downdraft tubes. No intensive study of orchard heater troubles was made in connection with the laboratory tests here reported. In general the test runs were of too short duration for characteristic troubles to develop fully. It is believed that these can be studied more satisfactorily in field tests such as are reported by Schoonover, Hodgson, and Young. ${ }^{(6)}$

It was found that refuse oil drained from crankcases of automobiles and tractors could be burned satisfactorily in several distilling type heaters.

\section{CAUTION NECESSARY IN USE OF DATA}

It is inadvisable to draw hard and fast conclusions as to the relative merits and demerits of the several heaters tested, using as a basis of comparison the data given in the summaries. This is particularly the case where the quantities measured were themselves very small. It should be remembered that the smaller the quantity, the less, in general, will be the degree of accuracy to which it can be measured. Also it should be borne in mind that the quantities measured were often changing appreciably from moment to moment. It was not in every case possible to take and to average a large number of readings for the reason that limited time was available when weather conditions were fit for making the tests. Nevertheless the data presented enable the making of a fair general comparison.

\section{SUMMARY}

New methods of testing were necessary because those used by mechanical engineers for testing furnaces were found inapplicable. Full description of methods is to be made in a later publication.

Nineteen heaters were studied and each was given a high and a low test in the open and a "normal" test indoors.

The burning rate was found important since it governs the rate of heat production. Each type of heater, if left without readjustment, was found to have a characteristic burning rate curve the shape 
of which was altered by changes in wind speed and air temperature and in temperature and volatility of the fuel. The burning rate is adjustable in most heaters. Too high a rate was found undesirable since it tends to increase smoke and losses by radiation and by gases rising too high. It also tends to cause rapid scaling off and destruction of the stacks. Frequent and careful regulation is highly desirable as a means of overcoming the smoke nuisance as well as of securing the desired heat production.

It is customary in many orchards to light only a portion of the heaters at first and light others as the night grows colder. From the standpoint of heat distribution and reduction in the amount of smoke it is better to light all of the heaters and burn them at a low rate with frequent regulation. This frequent regulation will control the burning rates of the heaters in such a way as to save considerable fuel. With briquet heaters the most practical way of controlling the burning rate is to start with a relatively small fuel charge and refuel at about two-hour intervals throughout the night.

All the heaters were found practically 100 per cent efficient from the standpoint of converting fuel into heat, there being almost no carbon monoxide in the gases and the heat lost in the unconsumed carbon of the smoke being in every case less than one-tenth of one per cent of the total heat in the fuel used.

The heat radiated above the horizontal plane ranged from about one to nearly five per cent of the total heat in the fuel. Not all of this radiated heat is lost. The portion that strikes leaves, twigs, or other opaque objects and is absorbed serves to warm the air. Baffles for decreasing the radiation loss were found practicable.

High upward velocities and high temperatures tend to waste fuel by sending the hot gases to high levels above the orchard. The velocities found were satisfactorily low except in high stack heaters not equipped with a horizontal baffle plate. In some of these velocities as high as 14 feet per second were found.

Smoke is always a nuisance and of little or no benefit as a blanket to prevent radiation. The lard-paid heaters were the worst offenders. A number of the later oil burners were practically smokeless when burned at normal and low rates, but all smoked some when burning at very high rates. Satisfactory control of the burning rate was in some cases made difficult if not quite impossible by ill-fitting reservoir covers in distilling type heaters. Briquet heaters smoke considerably at lighting and for a time afterward but become clearer as burning progresses. Photographic smoke records were made. 
No exhaustive study was made of orchard heater gases and smoke as affecting the public health. The concentrations of carbon monoxide are evidently too small to cause appreciable effects. Sulphur dioxide apparently caused annoyance to some of the workers. What part the smoke itself played was not determined.

Oils, being higher in heat content per pound, are more effective than solid fuels. The oils sold for orchard heating differ considerably in characteristics that affect their suitability. Oils that leave large asphaltic residues on burning are less desirable both for distilling and for non-distilling type heaters. A new method for determining per cent of residue is described. High sulphur content is objectionable. High viscosity and rapid increase in viscosity when temperature decrease make an oil unsuitable for non-distilling type heaters.

\section{ACKNOWLEDGMENTS}

The author wishes to express his grateful appreciation of advice and assistance received from his colleagues and from many others. Especial mention should be made of E. Ower, A. C. G. I.. of the British National Physical Laboratory who furnished unpublished data that enabled the calibration of the high-temperature anemometer; Professor L. B. Spinney of the Iowa State College and Dr. W. W. Coblentz and others of the U. S. Bureau of Standards who made valuable suggestions concerning the measurement of radiation; Dr. C. S. Bisson of the University of California who directed the chemical work; Dr. W. L. Howard, Professors R. W. Hodgson and A. H. Hendrickson of the University of California, Mr. Floyd D. Young of the U. S. D. A. Weather Bureau, and the members of the Research Committee of the American Society of Agricultural Engineers, who criticized the original plan of the work and read the manuscript. I am especially indebted to Mr. W. R. Schoonover of the University of California for a large number of practical suggestions for the orchardist which are made a part of this bulletin. 


\section{BIBLIOGRAPHY}

1 Garcia, F., and A. B. Fite

1922. Preliminary smudging experiments. New Mexico Agr. Exp. Sta. Bul. 134:1-26.

2 Henderson, Y., H. W. Haggard, M. C. Teague, A. L. Prince and

R. WUNDERLICH

1921. Reports of tunnel gas investigations, problem No. 2. Physiological effects of exhaust gases. N. Y. Bridge \& Tunnel Commission Report: Appendix 4, p. 166-168.

3 Kimball, H. H., and F. D. Young

1920. Smudging as protection from frost. Monthly Weather Review, 48:461-462.

4 O'GARA, P. J.

- 1910. The protection of orchards in the Pacific northwest from spring frosts by means of fires and smudges. U. S. Dept. Agr. Farmers' Bul. 401:1-24.

5 SAyers, R. R., F. V. Meriwether and W. P. Yant

1922. Physiological effects of exposure to low concentrations of carbon monoxide. U. S. Public Health Reports, May 12, 1922, Rept. 748:1.

6 Schoonover, W. R., R. W. Hodgson and F. D. Young

1925. Orchard heating in California. California Agr. Expt. Sta. Bul. 398:1-69.

7 WeBber, H. J., AND OTHERS

1919. A study of the effects of freezes on citrus in California. California Agr. Exp. Sta. Bul. 304:247-321.

8 West, F. L., AND N. E. EdLEFsen

1917. Orchard heating. Utah Agr. Exp. Sta. Bul. 161:1-48. 9 Young, F. D.

1922. Frost and the prevention of damage by it. U. S. Dept. Agr. Farmers' Bul. 1096:1-48.

10 1922. Frost studies in southern California citrus orchards. The California Citrograph (Los Angeles) 7:82-83.

11 1922. Notes on 1922 low temperatures. The California Citrograph 7: 196-197, 208-209.

12 1923. Frost investigation in southern California proves citrus groves can be protected. Citrus Leaves (Redlands, Calif.) 312:1-3, 19.

13 Young, F. D., and C. C. Cate

1923. Damaging temperatures and orchard heating in the Rogue River Valley, Oregon. Monthly Weather Review 51:617-639. 

No.

253. Irrigation and Soil Conditions in the Sierra Nevada Foothills, California.

262. Citrus Diseases of Florida and Cuba Compared with those of California.

263. Size Grades for Ripe Olives.

268. Growing and Grafting Olive Seedlings.

273. Preliminary Report on Kearney Vineyard Experimental Drain, Fresno County, California.

276. The Pomegranate.

277. Sudan Grass.

278. Grain Sorghums.

279. Irrigation of Rice in California.

283. The Olive Insects of California.

294. Bean Culture in California.

304. A Study of the Effects of Freezes on Citrus in California.

810. Plum Pollination.

312. Mariout Barley.

813. Pruning Young Deciduous Fruit Trees.

319. Caprifigs and Caprification.

824. Storage of Perishable Fruit at Freezing Temperatures.

325. Rice Irrigation Measurements and Experiments in Sacramento Valley, 1914-1919.

328. Prune Growing in California.

331. Phylloxera-Resistant Stocks.

835. Cocoanut Meal as a Feed for Dairy Cows and Other Livestock.

839. The Relative Cost of Making Logs from Small and Large Timber.

840. Control of the Pocket Gopher in California.

343. Cheese Pests and Their Control.

344. Cold Storage as an Aid to the Marketing of Plums.

346. Almond Pollination.

347. The Control of Red Spiders in Deciduous Orchards.

348. Pruning Young Olive Trees.

349. A Study of Sidedraft and Tractor Hitches.

350. Agriculture in Cut-over Redwood Lands.

353. Bovine Infectious Abortion.

354. Results of Rice Experiments in 1922

357. A Self-mixing Dusting Machine for Applying Dry Insecticides and Fungicides.

858. Black Measles, Water Berries, and Related Vine Troubles.

861. Preliminary Yield Tables for Second Growth Redwood.

362. Dust and the Tractor Engine.

363. The Pruning of Citrus Trees in California.

364. Fungicidal Dusts for the Control of Bunt.

365. Avocado Culture in California.

366. Turkish Tobacco Culture, Curing and Marketing.

367. Methods of Harvesting and Irrigation in Relation of Mouldy Walnuts.

368. Bacterial Decomposition of Olives during Pickling.

369. Comparison of Woods for Butter Boxes.

370. Browning of Yellow Newtown Apples.

371. The Relative Cost of Yarding Smal and Large Timber.

373. Pear Pollination.

374. A Survey of Orchard Practices in the Citrus Industry of Southern California.

375. Results of Rice Experiments at Cortena, 1923

376. Sun-Drying and Dehydration of Wal nuts.

377. The Cold Storage of Pears.

379. Walnut Culture in California.
380. Growth of Eucalyptus in California Plantations.

382. Pumping for Drainage in the San Joaquin Valley, California.

385. Pollination of the Sweet Cherry.

386. Pruning Bearing Deciduous Fruit Trees.

387. Fig Smut.

388. The Principles and Practice of Sundrying Fruit.

389. Berseem or Egyptian Clover.

390. Harvesting and Packing Grapes in California.

391. Machines for Coating Seed Wheat with Copper Carbonate Dust.

392. Fruit Juice Concentrates.

393. Crop Sequences at Davis.

394. Cereal Hay Production in California. Feeding Trials with Cereal Hay.

395. Bark Diseases of Citrus Trees.

396. The Mat Bean (Phaseolus aconitifolius).

397. Manufacture of Roquefort Type Cheese from Goat's Milk.

398. Orchard Heating in California.

399. The Blackberry Mite, the Cause of Redberry Disease of the Himalaya Blackberry, and its Control.

400. The Utilization of Surplus Plums.

401. Cost of Work Horses on California Farms.

402. The Codling Moth in Walnuts.

404. The Dehydration of Prunes.

405. Citrus Culture in Central California.

406. Stationary Spray Plants in California.

407. Yield, Stand and Volume Tables for White Fir in the California Pine Region.

408. Alternaria Rot of Lemons.

409. The Digestibility of Certain Fruit Byproducts as Determined for Ruminants.

410. Factors Affecting the Quality of Fresh Asparagus after it is Harvested.

411. Paradichlorobenzene as a Soil Fumigant.

412. A Study of the Relative Values of Certain Root Crops and Salmon Oil as Sources of Vitamin A for Poultry.

414. Planting and Thinning Distances for Deciduous Fruit Trees.

415. The Tractor on California Farms.

416. Culture of the Oriental Persimmon in California.

417. Poultry Feeding: Principles and Practice.

418. A Study of Various Rations for Finishing Range Calves as Baby Beeves.

419. Economic Aspects of the Cantaloupe Industry.

420. Rice and Rice By-products as Feeds for Fattening Swine.

421. Beef Cattle Feeding Trials, 1921-24.

422. Cost of Producing Almonds in California; a Progress Report.

423. Apricots (Series on California Crops and Prices)

424. The Relation of Rate of Maturity to Egg Production.

425. Apple Growing in California.

426. Apple Pollination Studies in California.

427. The Value of Orange Pulp for Milk Production.

428. The Relation of Maturity of California Plums to Shipping and Dessert Quality.

429. Economic Status of the Grape Industry. 
No.

87. Alfalfa

117. The Selection and Cost of a Small Pumping Plant.

127. House Fumigation.

129. The Control of Citrus Insects.

136. Melilotus indica as a Green-Manure Orop for California.

144. Oidium or Powdery Mildew of the Vine.

157. Control of the Pear Scab.

164. Small Fruit Culture in California.

166. The County Farm Bureau.

170. Fertilizing Californis Soils for the 1918 Crop.

173. The Construction of the Wood-Hoop Silo.

178. The Packing of Apples in California.

179. Factors of Importance in Producing Milk of Low Bacterial Count.

202. County Organizations for Rural Fire Control.

203. Peat as a Manure Substitute.

209. The Function of the Farm Bureau.

212. Salvaging Rain-Damaged Prunes.

215. Feeding Dairy Cows in California.

217. Methods for Marketing Vegetables in California.

230. Testing Milk, Oream, and Skim Milk for Butterfat.

231. The Home Vineyard.

232. Harvesting and Handling California Cherries for Eastern Shipment.

234. Winter Injury to Young Walnut Trees during 1921-22.

238. The Apricot in California.

239. Harvesting and Handling Apricots and Plums for Eastern Shipment.

240. Harvesting and Handling Pears for Eastern Shipment.

241. Harvesting and Handling Peaches for Eastern Shipment.

243. Marmalade Juice and Jelly Juice from Citrus Fruits.

244. Central Wire Bracing for Fruit Trees.

245. Vine Pruning Systems.

248. Some Common Errors in Vine Pruning and Their Remedies.

249. Replacing Missing Vines.

250. Measurement of Irrigation Water on the Farm.

252. Supports for Vines.

253. Vineyard Plans.

254. The Use of Artificial Light to Increase Winter Egg Production.

255. Leguminous Plants as Organic Fertilizer in California Agriculture.

256. The Control of Wild Morning Glory.

257. The Small-Seeded Horse Bean.

258. Thinning Declduous Fruite.
No.

259. Pear By-products.

261. Sewing Grain Sacks.

262. Cabbage Growing in California.

263. Tomato Production in California.

264. Preliminary Essentials to Bovine Tuberculosis Control.

265. Plant Disease and Pest Control.

266. Analyzing the Citrus Orchard by Means of Simple Tree Records.

267. The Tendency of Tractors to Rise in Front; Causes and Remedies.

269. An Orchard Brush Burner.

270. A Farm Septic Tank.

272. California Farm Tenancy and Methods of Leasing.

273. Saving the Gophered Citrus Tree.

276. Home Canning.

277. Head, Cane, and Cordon Pruning of Vines.

278. Olive Pickling in Mediterranean Coun. tries.

279. The Preparation and Refining of Olive Oil in Southern Europe.

281. The Results of a Survey to Determine the Cost of Producing Beef in Oali. fornis.

282. Prevention of Insect Attack on Stored Grain.

283. Fertilizing Citrus Trees in Californis,

284. The Almond in Californis.

285. Sweet Potato Production in California.

286. Milk Houses for California Dairies.

287. Potato Production in California.

288. Phylloxera Resistant Vineyards.

289. Oak Fungus in Orchard Trees.

290. The Tangier Pea.

291. Blackhead and Other Causes of Loss of Turkeys in California.

292. Alkali Soils.

293. The Basis of Grape Standardization.

294. Propagation of Deciduous Fruits.

295. The Growing and Handling of Head Lettuce in California.

296. Control of the Oalifornia Ground Squirrel.

298. The Possibilities and Limitations of Coöperative Marketing.

300. Coccidiosis of Chickens.

301. Buckeye Poisoning of the Honey Beo.

302. The Sugar Beet in California.

303. A Promising Remedy for Black Measles of the Vine.

304. Drainage on the Farm.

305. Liming the Soil.

306. A General Purpose Soil Auger and its Use on the Farm.

307. American Foulbrood and its Control.

308. Cantaloupe Production in California.

309. Fruit Tree and Orchard Judging.

The publications listed above may be had by addressing

College of Agriculture,

University of California,

Berkeley, California. 